\title{
Carpal tunnel syndrome : an epidemiological study
}

Citation for published version (APA):

de Krom, M. C. T. F. M. (1989). Carpal tunnel syndrome : an epidemiological study. [Doctoral Thesis, Maastricht University]. Rijksuniversiteit Limburg. https://doi.org/10.26481/dis.19890519mk

Document status and date:

Published: 01/01/1989

DOI:

10.26481/dis.19890519mk

Document Version:

Publisher's PDF, also known as Version of record

\section{Please check the document version of this publication:}

- A submitted manuscript is the version of the article upon submission and before peer-review. There can be important differences between the submitted version and the official published version of record.

People interested in the research are advised to contact the author for the final version of the publication, or visit the DOI to the publisher's website.

- The final author version and the galley proof are versions of the publication after peer review.

- The final published version features the final layout of the paper including the volume, issue and page numbers.

Link to publication

\footnotetext{
General rights rights.

- You may freely distribute the URL identifying the publication in the public portal. please follow below link for the End User Agreement:

www.umlib.nl/taverne-license

Take down policy

If you believe that this document breaches copyright please contact us at:

repository@maastrichtuniversity.nl

providing details and we will investigate your claim.
}

Copyright and moral rights for the publications made accessible in the public portal are retained by the authors and/or other copyright owners and it is a condition of accessing publications that users recognise and abide by the legal requirements associated with these

- Users may download and print one copy of any publication from the public portal for the purpose of private study or research.

- You may not further distribute the material or use it for any profit-making activity or commercial gain

If the publication is distributed under the terms of Article $25 \mathrm{fa}$ of the Dutch Copyright Act, indicated by the "Taverne" license above, 
CARPAL TUNNEL SYNDROME:

AN EPIDEMIOLOGICAL STUDY 



\section{CARPAL TUNNEL SYNDROME:}

\section{AN EPIDEMIOLOGICAL STUDY}

\section{PROEFSCHRIFT}

ter verkrijging van de graad van doctor aan de Rijksuniversiteit Limburg te Maastricht, op gezag van de Rector Magnificus, Prof.Dr. F.I.M. Bonke,

volgens het besluit van het College van Dekanen, in het openbaar te verdedigen op vrijdag, 19 mei 1989 om 16.00 uur

door

\section{MARCUS CORNELIS THOMAS FRANCISCUS MARIA DE KROM}

geboren te Goirle in 1948 
Beoordelingscommissie : Prof.Dr. F.T. Bosman (voorzitter), RL

Prof.Dr. J. Drukker, RL

Prof Dr. J. van Gijn, RUU

Prof.Dr. J.A. Knottnerus, RL

Prof.Dr. Sj. van der Linden, RL

\section{CIP-DATA KONINKLIJKE BIBLIOTHEEK, DEN HAAG}

Krom, Marcus Cornelis Thomas Franciscus Maria de

Carpal tunnel syndrome : an epidemiological study / Marcus

Cornelis Thomas Franciscus Maria de Krom. - [S.I. a s.n.].

- III.

Thesis Masstricht. w With ref. - With summary in Dutch.

ISBN 90-9002823-4

SISO 605.18 UDC 616.72:614.4(043.3)

Subject headings: carpal tunnel syndrome / epidemiology / surgery

Produktie:

Datawyse-Maastricht;

Th. A.M.J. van Lieshout, Secretariële ondersteuning.

Omslagontwerp:

De carpale tunnel: $H$. Rensema

Druk:

Krips Repro B.V., Meppel

De publicatie van dit proefschrift werd mogelijk gemaakt door financiële steun van Ciba Geigy BV, Katwijk Farma BV, Sanofi/Labaz BV, UCB Pharma Nederland B.V. en Wyeth Laboratoria BV. 
voor Elllen,

Caroline en Maarten 

CARPAL TUNNEL SYNDROME:

TABLE OF CONTENTS

CHAPTER

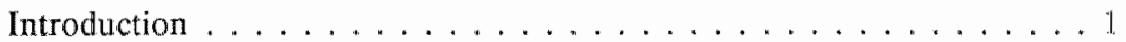

\section{CHAPTER 2}

The prevalence in the general population $\ldots \ldots \ldots \ldots$

\section{CHAPTER 3}

Risk factors ........................... 13

\section{CHAPTER 4}

The value of clinical diagnostic tests ................... 25

\section{CHAPTER 5}

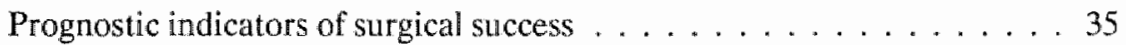

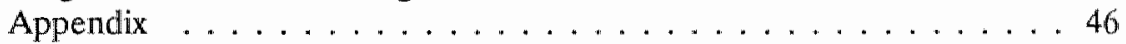

CHAPTER 6

General discussion .................................. 49

CHAPTER 7

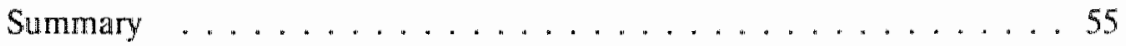

CHAPTER 8

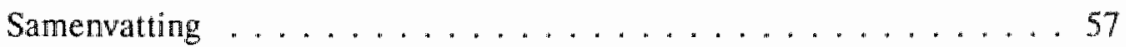

ACKNOWLEDGEMENT .................... 61

CURRICULUM VITAE ................... 63 



\section{CHAPTER 1 .}

\section{CARPAL TUNNEL SYNDROME:}

\section{INTRODUCTION}

At the out-patient department of neurology at the University Hospital Mastricht, a 55-year-old woman presented with chronic headache. Tests were performed to see whether a somatic cause could be found. The outcome after laborious examinations was that underlying pathology was unlikely. When the results were discussed with the patient, she asked whether sleeping problems might be a reason for her headache. She had been taking hypnotic drugs for several years without much success. She often woke up at night because of a "pins and needles" sensation in her right hand. Her GP had told her that her brachial plexus was compressed between her collar bone and the first rib, and he advised her not to carry heavy bags and to stop knitting, one of the patient's favourite hobbies. Most probably, he had not thought of carpal tunnel syndrome (CTS) as a possible cause. However, for the neurologist this was the first diagnosis to be considered in his differential diagnosis. He supposed that there was a connection with the knitting.

The physical examination was inconclusive, while some provocative tests were positive and others negative. The patient was referred for a neurophysiological examination, which revealed an obvious decrease in the nerve conduction velocity of the median nerve at the right wrist. The diagnosis of a rightsided CTS was made and told to the patient. She was advised to consult her GP again: it was her tingling fingers which kept her awake and also caused the headache. The therapy proposed to her was a surgical release of the carpal ligament of the right hand. She decided to have the operation. After the operation she went home the same day and that night she slept well for the first time in two years. Complaints of nocturnal brachialgia had disappeared, and the headaches had also become less severe since the CTS operation.

Case reports in the medical literature often deal with serious but rare diseases. CTS is not a rare disease but it is serious because the patient wakes up at night due to pins and needles in the median nerve innervated fingers. Although it is not a life-threatening disease, the quality of life is substantially affected. However, it appears that CTS can be cured with a simple surgical release of the median nerve in the carpal tunnel under regional anaesthesia and on an out-patient basis.

The case report which opens this chapter illustrates the possibility of unsuspected CTS. But there are also many patients with brachialgia in whom the GP supposes CTS 
to be the cause of their complaints. These patients are seen at the out-patient department of rheumatology, orthopedics, plastic surgery, general surgery and neurology. The University Hospital Maastricht, the Netherlands, covers the care of 150,000 people from Maastricht and the surrounding villages. About 120 CTS patients per year are seen at the out-patient department of neurology i.e. four per cent of all first ever consultations. Its diagnosis is based upon history and neurophysiological testing. The male:female ratio is estimated at $1: 4$.

It is a striking fact that most of these CTS patients are females in their postmenopausal years and that extensive history taking, physical and laboratory examinations hardly ever reveal a cause. This is in contrast with our findings in male CTS patients, in whom a relation with occupational activities can rather frequently be demonstrated.

On physical examination of patients with brachialgia we are often unable to find much support for the diagnosis of CTS from the different tests advocated by various textbooks and in the literature. Sometimes no abnormalities are found at all, whereas the same CTS related provocative tests may turn out to be positive in otherwise healthy persons without complaints of the hands.

In our clinic it is a rule that, in addition to a typical history of nocturnal brachialgia, all CTS patients must have abnormal findings at the median nerve conduction studies before they are referred for a surgical release of the median nerve. Details of the neurophysiological investigation methods will be presented below.

The preferred therapy of CTS proposed to our patients is surgical release of the median nerve under regional anaesthesia on an out-patient basis. This surgical therapy is in most cases very successful and most patients are found to be free of symptoms within three months after the operation.

It is surprising to note how few empirical studies have been published about CTS. The literature on this subject consists largely of case reports and uncontrolled studies in selected populations. Of course, some publications are highly informative, and these will be referred to in the following chapters. In general, we felt that new studies, especially in the general population, would be useful. Studying the general population prevents disease severity bias and referral bias and therefore adds to our knowledge of CTS in "extranural" medicine. We have opted for epidemiological methods to study four topics which will be dealt with in the next four chapters.

Chapter 2 reports on a cross-sectional survey of the prevalence of (undetected) CTS in the general population and the diagnostic value of nocturnal brachialgia.

Chapter 3 describes a population based case control study on prevalent risk indicators for CTS.

Chapter 4 evaluates the validity of various CTS related clinical diagnostic tests in a cross-sectional study in the general population.

Chapter 5 describes a non-experimental cohort study on the success of surgical 
release of the median nerve in relation to prognostic indicators. A series of consecutive CTS patients, operated upon for CTS, was followed up.

Chapter 6 presents a general discussion on the findings in this thesis.

For the prevalence survey (chapter 2) an age and sex stratified random sample was drawn from the population register of Maastricht, the Netherlands, and surrounding villages. Twice as many adult females as adult males were drawn. Respondents were interviewed using a standardized questionnaire, which included (among other things) health items, putative CTS risk indicators and CTS complaints. Participants with these complaints were invited to the out-patient department of neurology for a free physical and neurophysiological examination (chapters 2 and 4).

The risk profile of participants without CTS was compared with that of participants with newly detected CTS. In this etiological case-control study (chapter 3 ) the number of cases was augmented with a series of consecutive CTS patients who were to be operated upon.

Chapter 5 describes how these CTS patients, after being operated upon, were followed up in order to study the success rate of the operation in relation to prognostic indicators.

A flow chart of the numbers of participants, enrolled in the various studies is presented in table 1.

Why CTS is called a "syndrome" is not clear. It is a disease just like other diseases and carpal tunnel disease would be a more appropriate name. Nevertheless in this thesis we use the term "carpal tunnel syndrome", because this is common usage.

In our department diagnosis of CTS is based on clinical history and abnormal findings in the neurophysiological examination. The history is considered to be typical for CTS if it includes tingling, pain and/or numbness in the median nerve innervated fingers, with a frequency of twice a week or more, which in most cases wakes up the patient at night. A diagnosis of CTS has to be confirmed by abnormal findings at the neurophysiological examination, the methods of which will be presented below.

Sensory and motor nerve conduction was studied using surface electrodes for stimulating and recording. Sensory nerve action potentials (SNAPS) were recorded antidromically by means of ring electrodes around the fingers. The compound muscle action potential (CMAP) of the lateral thenar muscles was recorded using disk electrodes in belly-tendon montage. Median nerve distal motor latency (DML) was measured with stimulating and recording cathodes $7 \mathrm{~cm}$ apart. Median motor nerve conduction velocity (MNCV) was measured in the forearm. Median nerve sensory conduction velocity (SNCV) was measured from the wrist to digits II., III and IV and in the elbow-wrist segment. Ulnar nerve sensory conduction was measured from the wrist to digits IV and V. Distances between the median and ulnar stimulation sites at the wrist and the recording electrodes on digit IV were equal. At our department of clinical neurophysiology the difference in distal sensory latency (deltaDSL) to digit IV be- 
Table 1. Flow chart participants of the different studies.

Numbers of subjects studied. (Eligible subjects taken as a random sample from the general population of Maastricht (the Netherlands) and surrounding villages)

Eligible: $\quad 715$ subjects

Responders: 504 subjects* $(340)^{* *}$

\section{T S status}

\begin{tabular}{llll}
\hline unlknown & operated upon & \multicolumn{2}{l}{ earlier diagnosis } \\
& & CTS & CTS \\
& $\leq 1$ year $>1$ year & yes & no \\
& ago & ago & \\
\hline
\end{tabular}

waking up due to noctural brachialgia

\begin{tabular}{cccccc}
$\begin{array}{c}\text { no } \\
\text { yes }\end{array}$ & $\begin{array}{c}426(276) \\
64(51)\end{array}$ & $\overline{3(3)^{\# *}}$ & $\begin{array}{c}5(5) \\
3(2)^{\#}\end{array}$ & $\overline{2(2)}$ & $\overline{1(1)}$ \\
\hline total & $490(327)$ & $3(3)$ & $8(7)$ & $2(2)$ & $1(1)$
\end{tabular}

only subjects who reported waking up were examined further

neurophysiologically tested

\begin{tabular}{llllll} 
& $45(37)$ & - & $2(2)$ & $2(2)$ & $1(1)$ \\
not invited & -- & $3(3)$ & -- & -- & - \\
refused & $14(11)$ & -- & $1(0)$ & -- & - \\
no complaints anymore & $5(3)$ & -- & -- & -- & - \\
\hline
\end{tabular}

Numbers of CTS subjects selected for study from the eligible subjects operated upon for CTS in the University Hospital Maastricht, the Netherlands.

\begin{tabular}{ccc}
\hline Eligible first questionnaire & 180 & \\
responders & 128
\end{tabular}$\quad$ (24 men, 104 women)

Eligible second questionnaire $\quad 128$

deceased 2

non-tesponders $\quad 5$

form not usable 1

responders studied 120 (23 men, 97 women),

including 39 CTS operations on the left side, and 81 CTS operations on the right side.

\footnotetext{
* total number

** (women)

* complaints in the hand not operated upon
} 
tween median and ulnar nerve fibres is regarded as normal if it does not exceed 0.4 msec. At conduction distances of about $16 \mathrm{~cm}$ this corresponds with a difference in conduction velocities of about $7 \mathrm{~m} / \mathrm{s}$. In the wrist-finger segment differences of more than $7 \mathrm{~m} / \mathrm{s}$ in the SNCVs to the median nerve innervated digits II and III and the ulnar nerve innervated digit $V$ were also classified as abnormal. Our laboratory's upper normal limit for the median nerve DML is $4.5 \mathrm{msec}$. Skin temperature at the wrist was at least $32^{\circ} \mathrm{C}$ in all cases. Increased DML or slowing of nerve conduction in the segments between the wrist and digit II and between the wrist and digit III was not found to occur without delayed conduction in the median nerve fibres to digit IV (or absent SNAPs digit IV). In fact slowing was usually most pronounced in these fibres.

It is the opinion of several authors that with methods like those described above no more than five per cent of the CTS cases will be missed (1-5). It would seem that comparing the DSL of the median nerve with that of the ulnar nerve is the most reliable test for the detection of an entrapment of the median nerve in the carpal tunnel (6). Several authors prefer orthodromic measurements with palmar stimulation $(6,7)$, others use antidromic measurements with stimulation at the wrist and recording from the fingers $(1,2,8)$. Our upper normal value for differences in DSL to digit IV is 0.1 msec higher than that found by others $(1,2)$, and is in accordance with the value found by Redmond and Rivner, who used the orthodromic method (6).

We decided to take as our gold standard for CTS a combination of the typical history (see above) and abnormal nerve conduction of the median nerve at the wrist. Neurographic signs of polyneuropathy should be absent.

\section{REFERENCES}

1. Johnson EW, Kukla RD, Wongsam PE, Piedmont A. Sensory latencies to the ring finger: normal values and relation to carpal tunnel syndrome. Arch Pliys Med Rehabil 1981;62:206-208.

2. Brenninkmeyer $\mathbf{R}$. The carpal tunnelsyndrome and the antidromic sensory latencies to the first and the fourth finger. Abstracts 6th International Congress of Electromyography, Stockholm. Acta Neurol Scand 1979;suppl 73,60:119.

3. Buchtal F, Rosenfalck A, Trojaborg W. Electrophysiological findings in entrapment of the median nerve at wrist and elbow. J Neurol Neurosurg Psychiat 1974;37:340-360.

4. Duensing $\mathbb{F}$, Lowitzsch $K$, Thorwirth V, Vogel P. Neurophysiologische Befunde beim Karpaltunnelsyndrom. Korrelationen zum klinischen Befund. Z Neuro] $1974 ; 206: 267-284$. 
5. Ludin HP, Luetschg J, Valsangiacomo F. Vergleichende Untersuchung orthodromer und antidromer sensibler Nervenleitgeschwindigkeiten. 1. Befunde bei Nomalen und beim Karpaitumnelsyndrom. EEG EMG 1977;8(4):173-179.

6. Redmond $M D$, Rivner $\mathrm{MH}$. False positive electrodiagnostic tests in carpal tunnel syndrome. Muscle and Nerve 1988;11:511-517.

7. Stevens JC. AAEE minimonograph \#26: The electrodiagnosis of carpal tunnel syndrome. Muscle and Nerve 1987;10:99-113.

8. Spaans F. Lesions of the brachial plexus and upper limb nerves. In: Notermans SLH (ed) Current practice of clinical electromyography. pp 233-237, Amsterdam: Elsevier, 1984. 


\section{CARPAL TUNNEL SYNDROME:}

\section{THE PREVALENCE IN THE GENERAL POPULATION}

M.C.T.F.M. de Krom, MD*, P.G. Knipschild, MD ${ }^{*}$, A.D.M. Kester, PhD ${ }^{\text {\& }}$, P.J.M. van der Lugt, MD* , C.T. Thijs, MD ${ }^{*}$, P.F. Boekkooi, MD*

Departments of Neurology, ${ }^{*}$ Epidemiology and Health Care Research, "Medical InCormatics and Statistics, University Hospital Maastricht, University of Limburg, Maastricht, the Netherlands.

\section{ABSTRACT}

An age and sex stratified random sample of 715 subjects was taken from the population register of Maastricht and some surrounding villages (the Netherlands). Seventy percent, i.e. 504 subjects ( 164 men and 340 women) could be interviewed. Of these, 10 women had had an operation because of carpal tunnel syndrome (CTS). Two women had already been diagnosed as CTS patients, one had been neurophysiologically tested with normal results, and one man could not recall the reason for the operation on his wrist. Of the other subjects, 170 (53 men and 117 women) reported unpleasant feelings in their fingers. Waking up at night because of these sensations occurred in 64 (13 men and 51 women) of these interviewees.

Among these 64 subjects one man and 23 women were found to have CTS. This results in an age-standardized prevalence rate of undetected CTS of 5.8 per cent ( $95 \%$ confidence interval (CI): $3.5-8.1 \%$ ) in adult women. The prevallence in men appears to be very low.

The overall diagnostic value for a CTS of the complaint "waking up at night because of unpleasant finger sensations" is 38 per cent, while for women this is 45 per cent $(95 \%$ CI: $31-60 \%)$. 
Chronic entrapmint of the median nerve at the wrist is probably the most frequently encountered lesion of a peripheral nerve $(1,2)$. Patients typically have nocturnal pain, paraesthesiae and numbness involving the median nerve innervated fingers and are awakened by these symptoms. The pain often radiates up the arm towards or even beyond the elbow. Weakness is a less frequent complaint. These symptoms may also occur during the day. Both hands may be involved, but the dominant one is usually most affected (2). Physical findings are variable; sometimes no abnormalities are found. Diagnosis of CTS rests upon clinical history, signs and electrophysiological test$\operatorname{ing}(1,2,3)$.

Surgical treatment of this inconvenience is easy to perform and in most cases highly successful $(4,5)$.

Unfortunately it appears that CTS is frequently not recognized as the cause of tingling fingers or pain in the hand and arm. In our opinion this is due to the lack of familiarity with the signs and symptoms of this syndrome as well as with the high frequency of its occurrence. Recently a (hospital-based) study of the incidence of CTS in Rochester has been published: CTS cases were identified in the resources of the Rochester Epidemiology Program Project (6). So far no adequate epidemiological studies about the prevalence of CTS in the general population have been published $(7,8)$. Neither has the diagnostic value of various complaints in a patient's history which might suggest CTS been investigated.

In this study we report on the prevalence of undetected CTS in the general population. In order to contribute to an easier diagnosis of CTS we studied the diagnostic value of the symptom "waking up at night due to umpleasant sensations in the fingers".

\section{METHODS}

An age and sex stratified random sample was taken from the population register of Maastricht (The Netherlands) and some surrounding villages. Sample sizes were deliberately made equal for each of the age groups between 25 and 74 years. Since the prevalence was expected to be higher in women and to increase with age, we chose to have twice as many females as males in the sample. This overrepresentation of women and particular age-groups compared to the general population was intended to improve the accuracy of the estimates. Total sample size was 715 (232 men and 483 women), which allowing for a response rate of 75 per cent would yield estimates of the prevalence with a standard deviation of 1.6 per cent and 1.2 per cent respectively for a hypothesized true prevalence of five per cent.

The subjects were asked whether they were willing to be questioned by a trained interviewer. The goal of the survey was hidden: it was presented as a questionnaire about 
general health and health care. The important question for the present study was: "Do you wake up at night because of unpleasant sensations in your fingers?". At the end of the questionnaire all respondents were asked if they had been operated upon for CTS in the past.

All subjects who answered the question about having unpleasant sensations in their fingers in the affirmative, were Jater invited to the out-patient department of Neurology at the University Hospital Maastricht for a free neurological and neurophysiological examination. In a second interview at the hospital we asked these subjects if they had consulted their general practitioner about these complaints, and if so what diagnosis he had madle.

Details of the neurophysiological examination methods have been presented in chapter 1.

We decided to take as gold standard for CTS a combination of the typical history (i.e. paraesthesiae, numbness and/or pain in the median nerve innervated fingers twice a week or more frequently which in most cases wakes up the patient) and abnormal nerve conduction of the median nerve at the wrist. Neurographic signs of polyneuropathy should be absent.

Age- and sex-specific estimates of the prevalence rate were calculated by dividing the number of newly detected CTS patients by the number of interviewed persons. We assumed that all subjects refusing further examination were free of CTS, which means that the actual prevalence could be higher. For women a Dutch population age adjusted prevalence rate was calculated, together with its $95 \%$ confidence interval (CI) based on normal approximation.

The diagnostic value of the symptom "waking up at night because of unpleasant sensations in the fingers" was calculated only for subjects with a previously unknown status as far as CTS was concerned. In this calculation we took as a denominator the number of subjects who had not already been diagnosed as CTS patients or neurophysiologically tested for CTS and who woke up at night because of finger complaints. For the numerator, we took from the previously selected subjects only those with this complaint who had abnormal findings in the neurophysiological test. The point estimates of the diagnostic value were augmented by $95 \% \mathrm{CIs}$, based on the binomial distribution.

\section{RESULTS}

Table 1 shows the main results. Out of 715 eligible subjects, 504 ( 164 men and 340 women) were willing to be interviewed, i.e. a response rate of 70 per cent for both males and females. Of these 504 respondents, 10 women had had a CTS operation, two had already been diagnosed as CTS patients, one woman had shown normal values in the nerve conduction test one year before, and one man could not recall the reason for the wrist operation. Of the remaining 163 men and 327 women, 76 reported pain, 78 
Table 1. Prevalence of undetected CTS; diagnostic value of nocturnal finger complaints

\begin{tabular}{|c|c|c|c|c|c|c|c|c|c|c|c|c|}
\hline \multirow[t]{2}{*}{$\begin{array}{l}\text { age } \\
\text { groups }\end{array}$} & $\begin{array}{l}\text { A } \\
\text { inter } \\
\text { viewed } \\
\text { persons }\end{array}$ & $\begin{array}{l}\text { B } \\
\text { inter- } \\
\text { viewed } \\
\text { persons } \\
\text { without } \\
\text { CTS* }\end{array}$ & \multicolumn{2}{|c|}{$\begin{array}{l}\text { C } \\
\text { waking } \\
\text { up }\end{array}$} & \multicolumn{2}{|c|}{$\begin{array}{l}\text { D } \\
\text { neuro- } \\
\text { physiol. } \\
\text { tested }\end{array}$} & \multicolumn{2}{|c|}{$\begin{array}{l}E \\
\text { diffe- } \\
\text { rence in } \\
\text { sensory } \\
\text { latency } \\
>0.4 \mathrm{msec}\end{array}$} & \multicolumn{2}{|c|}{$\begin{array}{l}\text { E/A } \\
\text { preva- } \\
\text { lence of } \\
\text { undetec } \\
\text { ted CTS } \\
\text { (\%) }\end{array}$} & \multicolumn{2}{|c|}{$\begin{array}{l}\text { E/C } \\
\text { dia- } \\
\text { gnostic } \\
\text { value } \\
\text { waking } \\
\text { up }(\%)\end{array}$} \\
\hline & $\mathrm{m} \quad \mathrm{f}$ & $\mathrm{m} f$ & $\mathrm{~m}$ & & & & $\mathrm{~m}$ & $\mathrm{f}$ & $\mathrm{m}$ & & $\mathrm{m}$ & $\mathrm{f}$ \\
\hline $25-34$ & $\begin{array}{ll}35 & 65\end{array}$ & 64 & 1 & 5 & 1 & 4 & 0 & 0 & 0 & 0 & 0 & 0 \\
\hline $15-44$ & 34.70 & 67 & 1 & 7 & 1 & 7 & 0 & 4 & 0 & 6 & 0 & 57 \\
\hline $45-54$ & $28 \quad 66$ & $61^{*}$ & 5 & 15 & 2 & 11 & 0 & 6 & 0 & 9 & 0 & 40 \\
\hline $55-64$ & 3270 & 68 & 4 & 11 & 3 & 8 & 1 & 7 & 3 & 10 & 25 & 64 \\
\hline $65-74$ & $\begin{array}{ll}35 & 69\end{array}$ & 67 & 2 & 13 & 1 & 7 & 0 & 6 & 0 & 9 & 0 & 46 \\
\hline total & 164340 & 327 & 13 & 51 & 8 & 37 & 1 & 23 & 0.66 & & 8 & 45 \\
\hline
\end{tabular}

*Also excluding one woman with a previously normal nerve conduction test.

numbness and 115 tingling sensations in the fingers. One or more of these complaints was reported by 170 ( 53 men and 117 women) respondents. A total of 64 (13 men and 51 women) of these interviewees reported waking up at night because of unpleasant sensations in their fingers. These 64 subjects were invited to be examined in the hospital. Fourteen subjects refused further co-operation and another five said that they now had no nocturnal complaints in their fingers. They were not tested any further. Neurophysiological examination of the other 45 participants ( 8 men and 37 women) yielded abnormal results in one man (who had a right-sided CTS) and in 23 women (of whom 3 had a left-sided CTS and 4 a right-sided CTS, while the remaining 16 had bilateral (TS).

\section{PREVALENCE RATES OF UNDETECTED CTS}

It is mainly a matter of judgement which denominators must be used in the calculation of prevalence rates. We chose here to give conservative estimates: we assumed that the 14 persons with nocturnal finger complaints who refused further co-operation had normal nerve conduction velocities of the median nerve. We found only one male CTS patient, which indicates the low prevalence rate among men. Assuming the rate to be the same in all age classes considered, it can be estimated as 0.6 per cent, with a $95 \%$ Cl of $0-2$ per cent. Among the 327 women not previously diagnosed as CTS patients or tested for CTS, the complaint "waking up at night because of unpleasant finger sensations" was found in 51, i.e. 16 per cent. Among 37 of these who had their nerve conduction tested, positive proof of CTS was found in 23 , i.e. 7 per cent of the 
340 interviewed women. Table 1 shows the age-specific estimates of the prevalence rate of undetected CTS in females. The age-adjusted overall estimate taking the Dutch female population as the standard is 5.8 per cent, with a $95 \% \mathrm{Cl}$ of 3.5 to 811 per cent.

\section{Diagnostic VAlue}

Table 1 also presents the data concerning the diagnostic value of the symptom "waking up at night because of unpleasant finger sensations". In patients with an unknown status as far as CTS was concerned we arrive at a diagnostic value of this complaint for the presence of CTS of $24: 64=38$ per cent. For men, the overall estimate is 8 per cent, with a $95 \% \mathrm{CI}$ of $0-36$ per cent, whereas for women the overall estimate is $23: 51=45 \%$, with a $95 \%$ CI of $31-60 \%$.

\section{GPS DIAGNOSIS IN SUBJECTS WITHOUT A PREVIOUS DIAGNOSIS OF CTS}

Only 23 of the 45 subjects who were given a second interview had consulted their GP about finger complaints. One woman did so after she had been interviewed and before our examination in the hospital and she appeared to have CTS. Two subjects did not get or could not recall the GP's diagnosis. One reported that her GP had told her she had a CTS, which we could not confirm. The subjects who eventually turned out to have CTS said that their GP had told them that their symptoms were due to a variety of causes including cervical root compression (one subject), vascular disease (two subjects), surmenage (one subject), and other reasons (seven subjects).

\section{Discussion}

From our data CTS, as diagnosed according to our criteria, appears to be a frequently encountered disorder in women: 5.8 per cent of all adult (25-74 yrs) women can be expected to suffer from CTS but go undetected, while another 3.4 per cent $(95 \% \mathrm{Cl}$ : $1.5-5.3 \%$ ) (age-adjusted estimate) have already been diagnosed as CTS. The owerall prevalence rate for men however must actually be low.

We do not feel that the response rate of 70 per cent influenced our data, since the questions about finger complaints were hidden among a great number of other questions, concerning professional activities, way of life, eating habits, common chronic diseases, etc. Nor are there reasons to suppose GPs in Maastricht and surrounding villages are less alert to CTS when compared to GPs elsewhere. Comparing our prevalence figures with the Rochester CTS incidence study is hardly possible in that we detected CTS cases in the general population and all our cases had CTS diagnosed not only on the basis of their positive history, but also on the basis of electrophysiological 
testing (6).

It would seem useful to repeat our study in other countries, to see if the prevalence of undetected CTS is as high as that in our population.

Possible explanations for this high prevalence rate include:

1. CTS is not a fatal disease, so with increasing age a rising prevalence rate is to be expected. The data in Table 1 support this view.

2. Neither patients nor doctors recognize CTS as the cause of unpleasant finger complaints. So effective treatment will not be sought.

We have shown the diagnostic value for CTS of the complaint "waking up at night because of unpleasant finger sensations" to be as high as 45 per cent for women and 38 per cent for men and women together.

In conclusion the question: "Do you wake up at night because of unpleasant sensations in your fingers?" turns out to be a simple screening device with a high diagnostic value for CTS. Perhaps in the future this could help lower the present prevalence rate of 5.8 per cent of undetected CTS in Dutch women between 25 and 74 years of age.

\section{REFERENCES}

1. Heywood PL. Through the carpal tunnel. BMJ 1987;294:660-661.

2. Anonymous. Diagnosis of the carpal tunnel syndrome (editorial). Lancet $i$, $1985 ; 854-858$.

3. Aebi-Ochsner C, Ludin HP. Das Karpaltunnelsyndrom--Klinische Symptomatologie und Elektrophysiologische Befunde. Fortschr Neurol Psychiatr 1979;47:307-319.

4. Mühlau $\mathrm{G}$, Both $\mathrm{R}$, Kunath $\mathrm{H}$. Carpal tunnel syndrome-course and prognosis. J Neurol 1984;231:83-86.

5. Harris CM, Tanner E, Goldstein MN, Pettee DS. The surgical treatment of the carpal-tunnel syndrome correlated with preoperative nerve-conduction studies. J Bone Joint Surg 1979;61A,1,93-98.

6. Stevens JC, Sun S, Beard CM, O'Fallon WM, Kurland LT. Carpal tunnel syndrome in Rochester, Minnesota, 1961 to 1980 . Neurology 1988;38:134-138.

7. Bleecker ML, Bohlman M, Moreland R, Tipton A. Carpal tunnel syndrome: Role of carpal canal size. Neurology 1985;35:1599-1604.

8. Kelsey JL. Epidemiology of musculoskeletal disorders. Monographs in epidemiology and biostatistics. Oxford University Press, New York, Oxford; 1982:168-191. 


\section{CHAPTER 3}

\section{CARPAL TUNNEL SYNDROME:}

\section{RISK FACTORS}

M.C.T.F.M. de Krom, MD ${ }^{*}$, A.D.M. Kester, PhD ${ }^{\&}$, P.G. Knipschild, MD ${ }^{\#}$, P.J.M. van der Lugt, MD*

Departments of *Neurology, \& Medical Informatics and Statistics, "Epidemiology and Health Care Research, University Hospital Maastricht, University of Limburg, Maas tricht, the Netherlands.

\section{ABSTRACT}

A case control study of CTS risk factors in the general population is described. Control subjects were 501 persons (164 men, 337 women) taken as an age and sex stratified random sample from the population register of Maastricht (the Netherlands) and surrounding villages. All were given a standardized questionnaire with items on general health, potential CTS risk factors, CTS complaints etc.

Twenty-eight of the 501 participants were found to suffer from CTS. These 28 were added to a series of 128 consecutive CTS patients from the same area. The 156 (131 women, 25 men) subjects in whom CTS had been diagnosed on the basis of clinical history and neurophysiological testing were compared with the remaining 473 (310 women, 163 men) subjects. After adjustment for age and sex the following CTS risk factors could be identified:

1. Activities with a flexed wrist resulted in an exposure-related increased risk. The risk ratio ( $R$ R) increased from 2.8 (95\% confidence interval $(\mathrm{CI}): 1.8-4.3)$ for 8 hours of work per week to 4.3 (95\% CI: 2.3-8.0) for 40 hours of work per week.

2. Activities with an extended wrist resulted in an exposure-related increased risk. RR increased from $1.4(95 \% \mathrm{Cl}: 1.0-1.9)$ for 8 hours of work per week to $5.4(95 \% \mathrm{Cl}$ : $1.1-27.4$ ) for 40 hours of work per week.

3. Hysterectomy without oophorectomie: RR 2.0 (95\% CI: $1.1-3.6)$.

4. Last menstrual period in menopausal women without a hysterectomy six to 12 months ago: RR 6.5 (95\% CI: 1.9-21.8).

5. Height: RR per cm increase 0.96 (95\% CI: 0.93-0.98). 
6. Weight: RR per kg increase 1.02 (95\% CI: 1.00-1.03).

7. Quetelet index: RR per kg/m $\mathrm{m}^{2} 1.09$ (95\% CI: 1.04-1.14).

8. Slimming courses: RR 2.1 (95\% CI: $1.4-3.1)$.

9. Varicosis in men: RR 12.0 (95\% CI: $3.6-40.1)$.

Associations of CTS with the use of oral contraceptives, age at menopause, diabetes, thyroid dysfunction, rheumatism, typewriting or pinch grasp could not be demonstrated.

\section{INTRODUCTION}

The carpal tumnel syndrome (CTS) is a frequently encountered peripheral nerve lesion in women in our region. It has been diagnosed in about four per cent of the women between 25 and 74 years of age, while unrecognized CTS has been estimated to occur in another six per cent as the cause of brachialgia (1). Nearly half of the cases with brachialgia turn out to have CTS (2).

Numerous papers on the possible etiology of CTS have been published. Various authors have tried to summarize the putative causes (2-8). An attempt to order them may be the following classification:

1. An increase in volume of the contents of the carpal tunnel, whether due to injury, various diseases or haemodialysis.

2. A decrease in the volume of the carpal tunnel, whether congenitally determined or due to deformation of the bone trough.

3. Thickening of the transverse carpal ligament.

4. Anomalous structures within the tunnel.

5. Pathological influences of mechanical stresses such as the performance of frequent repetitive hand movements, forceful grasping with the fingers, pinching, or the use of vibrating hand tools.

6. Endocrinological factors such as thyroid diseases, diabetes mellitus, pregnancy, the use of otal contraceptives, acromegaly.

No case control study of the determinants of CTS incidence has so far been performed with general population controls. Using a population-based case control design, we have studied the role of various suggested CTS risk factors.

\section{Methods}

An age and sex stratified random sample was taken from the population register of Maastricht (the Netherlands) and some surrounding villages. We chose to have equal age groups between 25 and 74 years and twice as many females as males in the sample. Total sample size was 715 ( 232 men and 483 women). 
The subjects were asked whether they were willing to be questioned by a trained interviewer. The goal of the survey was hidden: it was presented as a questionnaire about general health and health care. Questions concerned life style habits, chronic diseases, potential CTS risk factors and CTS complaints.

Potential CTS risk factors were considered to be:

1) different hand and finger positions: working with the extended or flexed wrist, typewriting, pinch grasp and the duration of these hand activities, i.e. the exposure;

2) female related factors: menarche, number of pregnancies, age at menopause, use of progestative or estrogen substances, hysterectomy with or without oophorectomy;

3) height, weight, Quetelet index;

4) co-existing diseases, the diagnosis of which had been revealed to the subjects by a physician: fractures of the wrist, thyroid diseases, diabetes, rheumatism.

Among those subjects who reported CTS complaints in the questionnaire, CTS patients were identified by means of a second interview and neurophysiological testing (1). These newly found CTS patients were added to a series of consecutive CTS patients from the out-patient department of neurology at the University Hospital Maastricht, the only hospital in the area. The CTS patients were given the same questionnaire as the control subjects on the day of their CTS operation. All cases were living in the same area as the controls.

The cases had their CTS diagnosed on the basis of clinical history and neurophysiological examination. Details of the neurophysiological examination methods have been presented in chapter 1 . We decided to take as our gold standard for CTS a combination of the typical history (i.e. paraesthesiae, numbness and/or pain in the median nerve innervated fingers with a frequency of twice a week or more, which in most cases wakes up the patient) and abnormal nerve conduction of the median nerve at the wrist. Neurographic signs of polyneuropathy should be absent.

\section{STATISTICAL ANALYSIS}

For each of the potential CTS risk factors considered we calculated the numbers of cases and controls at each level of the factor; for continuous variables such as weight, the mean and standard deviations. Risk ratios (RR) were estimated as odds ratios for each factor separately from a multiple logistic regression model including the stratification variables sex, age (in five decade groups) and their interaction, in order to enhance the accuracy of the estimates. The risk of activities with the wrist was estimated by fitting the mean duration per week of these activities as continuous variables after truncation at $40 \mathrm{~h} /$ week to avoid undue influence of very large exposures. The natural logarithm of this exposure was fitted in cases where this resulted in a better fit. We then used the estimated coefficient to calculate estimated RR at exposures of 8,20 and 40 hours per week. 


\section{Table 1. CTS risk factors}

Classiffeation of cases and controls on the basis of their different activities, estimated risk ratios (RR) and their $95 \%$ confidence intervals (CI) and $\mathrm{X}^{2}$-tests

\begin{tabular}{llll}
\hline mean exposure per week Cases Controls & RR for $95 \% \mathrm{CI}$ & $\mathrm{X}^{2}$ \\
$0-5$ years ago & upper & \\
& & limit \\
& of & \\
& & category \\
& & \\
\hline
\end{tabular}

Activities with flexed** wrist 0-5 years ago

$\begin{array}{lrrrrc}0 \quad \text { hours } & 112 & 421 & 1 & & \\ 1-8 \text { hours } & 17 & 25 & 2.8 & 1.8-4.3 & 20.3 \\ 8-20 \text { hours } & 15 & 17 & 3.5 & 2.1-6.1 & \mathrm{p}<0.001 \\ 20-40 \text { hours } & 12 & 10 & 4.3 & 2.3-8.0 & \end{array}$

Activities with extended wrist

$\begin{array}{crrccc}0 \quad \text { hours } & 134 & 417 & 1 & & \\ 1-8 \text { hours } & 14 & 47 & 1.4 & 1.0-1.9 & 4.3 \\ 8-20 \text { hours } & 4 & 6 & 2.3 & 1.0-5.2 & p=0.038 \\ 20-40 \text { hours } & 4 & 3 & 5.4 & 1.1-27.4 & \end{array}$

Activities with extended and flexed wrist in combination

$\begin{array}{rrrrrc}0 \text { hours } & 101 & 290 & 1 & & \\ 1-8 \text { hours } & 20 & 80 & 1.1 & 0.9-1.2 & 0.9 \\ 8-20 \text { hours } & 17 & 50 & 1.2 & 0.8-1.7 & \mathrm{p}=0.33 \\ 20-40 \text { hours } & 18 & 53 & 1.4 & 0.7-2.9 & \end{array}$

Pinch grasp**

$\begin{array}{rrrrrc}0 \text { hours } & 102 & 275 & 1 & & \\ 1-8 \text { hours } & 33 & 101 & 0.7 & 0.5-1.1 & 2.24 \\ 8-20 \text { hours } & 14 & 58 & 0.7 & 0.4-1.1 & \mathrm{p}=0.13 \\ 20-40 \text { hours } & 7 & 39 & 0.7 & 0.4-1.1 & \end{array}$

\section{typewriting**}

0 hours

1- 8 hours

8-20 hours

$20-40$ hours

$\begin{array}{rrllc}144 & 416 & 1 & & \\ 4 & 13 & 0.8 & 0.5-1.3 & 1.0 \\ 3 & 18 & 0.7 & 0.3-1.4 & \mathrm{p}=0.32 \\ 5 & 26 & 0.7 & 0.3-1.5 & \end{array}$

*truncated at 40 h/week

** log transformed for analysis 
For those factors not exclusively applicable to females, the interaction with gender was tested and reported when significant at the 0.05 level. The estimated RR were supplemented with $95 \%$ confidence intervals $(\mathrm{CI})$, based on asymptotic standard errors of the estimated log odds ratios. For factors with more than two ordered levels a likelihood ratio chi square test for trend was performed by fitting the factor as a contimuous variate. In general we aimed at evaluating risk factors only for persons who could have been exposed to that factor. For instance, the risk of oral contraceptives was estimated only for women who had had their last menstrual period not longer than one year ago.

To take account of possible interactions and other relations between risk factors, a further model was fitted, including the factors that turned out to be important in the previous analyses, plus those factors that were considered to be related to these. Stepwise, the factors which did not contribute to the goodness of fit and did not substantially influence the estimated coefficients of other factors, were deleted from this model.

\section{RESULTS}

Out of 715 eligible subjects from the general population, 501 persons ( 164 men, 337 women) were willing to be interviewed, i.e. a response rate of $70 \%$ for both males and females. Twenty-eight ( 27 women, one man) of the 501 interviewed persons were found to have CTS. Out of 180 consecutive eligible CTS patients from the out-patient department of neurology, 128 were co-operative (104 women, 24 men), a response rate of $71 \%$. So eventually 156 CTS cases ( 131 women, 25 men) could be compared with 473 controls ( 310 women, 163 men) from the general population as regards the various risk factors. Tables 1 to 5 below present calculated odds ratios which can be regarded as estimated RR for the various factors considered. The RR are accompanied by their $95 \% \mathrm{CI}$ based on normal approximation of the log odds ratio.

Table 1 shows the numbers of cases and controls in categories of exposure to working with different hand and finger positions. For exposure to flexion and pinch grasp, the log transform was used in the subsequent analysis. The other exposures were not transformed. Estimated RR are given at exposures of 8,20 and 40 hours per week. It was found that the risk of CTS increased with the number of hours of work with the flexed or extended wrist over the past five years. A mean exposure to flexion of 8 hours per week over the past five years resulted in a RR of $2.8,20$ hours in a RR of 3.5 , and 40 hours in a RR of 4.3. Activities with the extended wrist for 8 hours per week resulted in a RR of 1.4, 20 hours in a RR of 2.3 , and 40 hours in a RR of 5.4. For both activities a clear dose-effect relation could be shown. In contrast, working with the flexed and extended wrist in combination over the past five years did not carry a significantly increased RR and the same goes for pinch grasp and typewriting.

Table 2 shows the female-related CTS risk factors. It was found that women who had had a hysterectomy without oophorectomy run a risk for CTS which is twice as high as that for women who were not operated upon. Age at menopause for all postmenopausal women and age at menopause for women older than 59 years, age at menarche, number of pregnancies or diabetes during pregnancy could not be shown to 
Table 2. CIS risk factors.

Classification of cases and controls over female related factors, estimated risk ratios (RR) and their $95 \%$ confidence intervals $(\mathrm{Cl})$ and $\mathrm{X}^{2}$-tests

\begin{tabular}{lllll} 
Cases Controls RR & R & $\mathrm{X}^{2}$ \\
\hline
\end{tabular}

\section{Hysterectomy}

$\begin{array}{lrrll}\text { no } & 94 & 268 & 1 & \\ \text { without oophorectomy } & 27 & 30 & 2.0 & 1.1-3.6 \\ \text { with oophorectomy } & 8 & 10 & 2.0 & 0.7-5.3 \\ \text { in menopause } & 2 & 2 & 2.9 & 0.4-21.9\end{array}$

Age at menopause

$\begin{array}{lrrrrc}<45 & 7 & 19 & 1.3 & 0.5-3.6 & 0.09 \\ 45-50 \text { years } & 7 & 32 & 0.8 & 0.3-2.1 & \mathrm{p}=0.76 \\ >50 \text { years } & 18 & 66 & 1 & & \end{array}$

Age at menopause for women older than 59 years

$\begin{array}{lrrllc}\text { menopause }<45 \text { years } & 3 & 13 & 0.9 & 0.2-3.8 & 0.003 \\ \text { menopause } 45-50 \text { years } & 5 & 18 & 1.1 & 0.3-3.6 & \mathrm{p}=0.95 \\ \text { menopause }>50 \text { years } & 12 & 48 & 1 & & \end{array}$

Years since last menstrual period (only for menopausal women without hysterectomy)
$\leq 1$ year
129
6.5
1.9-21.8
9.3
$2-5$ years

$7 \quad 13$
2.4
$0.8-7.5$
$\mathrm{p}=0.002$
$>5$ years
$25 \quad 104$

$$
1
$$

Age at menarche (no menarche in 1 case and 2 controls)

$\begin{array}{lrrllc}<12 \text { years } & 12 & 44 & 0.6 & 0.3-1.2 & 0.49 \\ 12-15 \text { years } & 103 & 227 & 1 & & \mathrm{p}=0.49 \\ >15 \text { years } & 15 & 37 & 0.8 & 0.4-1.6 & \end{array}$

Number of pregnancies

$\begin{array}{lrrrrc}\text { none } & 19 & 51 & 1 & & \\ 1 \text { or } 2 & 54 & 143 & 0.8 & 0.4-1.5 & 0.094 \\ 3 \text { or more } & 58 & 116 & 1.0 & 0.5-1.9 & p=0.76\end{array}$

Diabetes during pregnancy

$\begin{array}{lrrll}\text { no } & 101 & 244 & 1 & \\ \text { yes or possible } & 11 & 15 & 1.6 & 0.7-3.7\end{array}$

Use of oral contraceptives (OC) during last 5 yrs (last menstrual period less than 1 year ago)

$\begin{array}{llllll}\text { no } \mathrm{OC} & 42 & 88 & 1 & & \\ 1-4 \text { years } & 10 & 48 & 0.7 & 0.3-1.6 & 0.82 \\ 25 \text { years } & 10 & 15 & 2.0 & 0.8-5.2 & \mathrm{p}=0.37\end{array}$


be risk factors for CTS. Moreover, in women who had their last menstrual period not longer than one year ago the use of oral contraceptives during the last five years could not be related to a higher risk for CTS.

Postmenopausal women who had had their last menstrual period no longer than 12 months ago have a RR for CTS of 6.5 . Those who had had it 2-5 years ago have a RR of 2.4 .

Table 3 shows the RR of height, weight, Ouetelet index and slimming courses for CTS: height was associated with a RR of 0.96 per centimeter increase. That is to say that if a person is $15 \mathrm{cms}$ taller, the risk for CTS is about halved. On the other hand being $15 \mathrm{cms}$ shorter doubles the risk for CTS. Per kilogram increase, weight showed a RR of 1.02 . So, a weight increase of $30 \mathrm{kgs}$ is associated with a RR of 1.6. Per kilogram per square meter increase the Quetelet index showed a RR of 1.09.

Subjects who had taken slimming courses were 2.1 times more at risk of having CTS.

Table 4 gives the figures for coexisting diseases as risk factors for CTS. Wrist fractures, thyroid diseases (which were only present in women), rheumatism and diabetes could not be shown to be risk factors for CTS. The same was true for varicosis in women, but in men varicosis was found to result in an extremely increased RR for CTS.

Table 5 presents the estimated coefficients for the final model, including all important factors. The coefficients are estimates of the log odds ratios after correction for the other factors included, and for sex, age and their interaction. No interactions were found between any of the included factors. Weight and having taken slimming courses in the past are both in the model, and are somewhat correlated. Deleting one of these two increases the coefficient of the other. The last five entries in the table concern women only. The table allows computation of the relative risk from several factors together: for instance, being $10 \mathrm{cms}$ shorter and $5 \mathrm{kgs}$ heavier results in a log odds ratio of $-10 \times-0.055+5 \times 0.014=0.62$. The risk ratio is antilog $(0.62)=1.86$.

\section{Discussion}

So far, no case control study of the etiology of CTS has been performed using controls from the general population.

Neither, as a rule, was the diagnosis of CTS based on clinical history as well as neurophysiological testing in other studies. Therefore it is difficult to compare our results with the findings from other studies.

Furthermore, in our study controls were neurophysiologically tested if they had nocturnal complaints in their fingers which woke them up. This yielded 28 CTS patients from the general population who were added to a series of 128 CTS patients from the same area. Thus, it might be said that we cleared the general population of CTS patients, which enabled us to make the best possible comparison between CTS cases and general population controls.

Our study has shown that activities with the flexed wrist (such as grasping or packing of e.g. tiles) result in a more than two-fold increase of the risk for CTS, while the $\mathrm{RR}$ is also positively correlated with the duration of these activities. In the same way 
Table 3. CTS risk factors

Classification of cases and controls over physical parameters and slimming courses, estimated risk ratios (RR) and their $95 \%$ confidence intervals (CI)

\begin{tabular}{|c|c|c|c|c|}
\hline & $\begin{array}{c}\text { Cases } \\
\mathrm{n}=156 \\
\text { mean }(\mathrm{SD})\end{array}$ & $\begin{array}{c}\text { Controls } \\
n=473 \\
\text { mean (SD) }\end{array}$ & RR & $95 \% \mathrm{Cl}$ \\
\hline height (cm) & $164(7.3)$ & $168(8.4)$ & 0.96 & $0.93-0.98$ \\
\hline weight $(\mathrm{kg})$ & $68(12.5)$ & $68(11.9)$ & 1.02 & $1.00-1.03$ \\
\hline Quetelet index $\left(\mathrm{kg} / \mathrm{m}^{2}\right)$ & $25(4.0)$ & $24 \quad(3.7)$ & 1.09 & $1.04-1.14$ \\
\hline & $\begin{array}{c}\text { cases } \\
\mathrm{n}\end{array}$ & $\begin{array}{c}\text { controls } \\
n \\
\end{array}$ & RR & $95 \% \mathrm{CI}$ \\
\hline $\begin{array}{l}\text { slimming courses no } \\
\text { yes }\end{array}$ & $\begin{array}{l}92 \\
64\end{array}$ & $\begin{array}{l}360 \\
113\end{array}$ & $\begin{array}{l}1 \\
2.1\end{array}$ & $1.4-3.1$ \\
\hline
\end{tabular}

* estimated risk ratio per unit increase of the parameter.

Table 4. CTS risk factors. Classification of cases and controls over coexisting disease, estimated risk ratios (RR) and their $95 \%$ confidence intervals (CI)

\begin{tabular}{|c|c|c|c|c|}
\hline & Cases & Controls & RR & $95 \% \mathrm{CI}$ \\
\hline \multicolumn{5}{|c|}{$\begin{array}{l}\text { Varicosis* } \\
\text { men }\end{array}$} \\
\hline no & 17 & 155 & 1 & \\
\hline yes & 8 & 8 & 12.0 & $3.6-40.1$ \\
\hline \multicolumn{5}{|c|}{ women } \\
\hline no & 88 & 203 & 1 & \\
\hline yes & 43 & 107 & 0.9 & $0.6-1.4$ \\
\hline \multicolumn{5}{|c|}{ Wrist fracture } \\
\hline no & 147 & 428 & 1 & \\
\hline yes & 9 & 45 & 0.7 & $0.3-1.5$ \\
\hline \multicolumn{5}{|c|}{ Thyroid disease (only found in women) } \\
\hline no & 124 & 294 & 1 & \\
\hline yes & 7 & 16 & 1.0 & $0.4-2.6$ \\
\hline \multicolumn{5}{|c|}{ Rheumatism } \\
\hline no & 153 & 450 & 1 & \\
\hline yes & 3 & 23 & 0.3 & $0.1-1.2$ \\
\hline \multicolumn{5}{|c|}{ Diabetes } \\
\hline no & 152 & 456 & 1 & \\
\hline yes & 4 & 17 & 0.6 & $0.2-2.0$ \\
\hline
\end{tabular}

* the RR of varicosis was different for men and women. 
Table 5. CTS risk factors

Factors in final model and estimated log odds ratios

\begin{tabular}{llll}
\hline Risk factor & $\begin{array}{l}\text { units or } \\
\text { stratum }\end{array}$ & $\begin{array}{l}\text { estimated } \\
\text { log odds ratio }\end{array}$ & $\begin{array}{l}\text { standard } \\
\text { error }\end{array}$ \\
\hline Weight & $\mathrm{kg}$ & 0.014 & 0.011 \\
Height & $\mathrm{cm}$ & -0.055 & 0.018 \\
Slimming courses: & & & \\
$\quad$ no & & 0 & 0 \\
yes & & 0.46 & 0.25 \\
Wrist activities: & $\log (\mathrm{h} / \mathrm{wk}+0.2)$ & 0.25 & 0.065 \\
flexion & $\mathrm{h} / \mathrm{wk}$ & 0.041 & 0.022 \\
extension & & & \\
Varicosis: & & 0 & 0 \\
men: no & & 2.22 & 0.65 \\
$\quad$ yes & & 0 & 0 \\
women: no & -0.17 & 0.25 \\
$\quad$ yes & & \\
Female related: & & \\
premenopausal, & & 0 & 0 \\
no hysterectomy & & 0.88 & 0.55 \\
menopause last year & & -0.05 & 0.62 \\
$\quad$ 2-5 yrs ago & & -0.69 & 0.54 \\
" > 5 yrs ago & & 0.59 & 0.38 \\
hysterectomy & &
\end{tabular}

the RR for CTS of activities with the extended wrist (such as scrubbing or ironing) is found to increase the longer the subjects are exposed. As for the duration of both activities, a clear trend of increase in RR was found.

Flexion of the wrist will lead to a compression of the flat median nerve between the flexor retinaculum and the flexor tendons (8-12). Flexion and extension of the wrist have been shown to raise the pressure in the carpal tunnel which causes neurophysiological changes and hand complaints (13). These measurements are in complete agreement with our own epidemiological findings. To our surprise the association between combined activities of the wrist in flexion and extension and CTS was a rather weak one.

In order to assess whether a possible referral bias or disease severity bias for CTS patients from the general population could have played a role, we repeated the analyses using only the 128 CTS patients from the out-patient department and the 473 controls from the general population. This resulted in essentially the same figures for the RR for CTS regarding activities with the flexed or the extended wrist and all other 
risk factors considered below.

Pinch hand position has been demonstrated to be positively associated with CTS (14). We were unable to confirm the results of this study.

Association of CTS and previous hysterectomy has already been demonstrated $(16,17)$. Our epidemiological study confirms the results of these studies: we demonstrated prewious hysterectomy without oophorectomy to carry a RR for CTS of 2.0 . As for this finding various hypotheses may be drawn up:

1. our finding is merely coincidental; Silverstein's study did not show any association. between symptoms of CTS and hysterectomy or bilateral oophorectomy (18);

2. with hysterectomy a special protective factor is removed which leads to the development of CTS;

3. patients who are about to have a hysterectomy will have a greater chance of detection of their CTS, because they are seen by more doctors than subjects from the general population without a bysterectomy.

We were unable to identify age at menopause as a risk factor for CTS: women under 45 years of age had a RR for CTS of 1.3, while women who had their menopause between 45 and 50 years had a RR of 0.8 . Women who had their menopause at an age over 50 years were chosen as reference. To avoid any confounding with age caused by selecting (post)menopausal women for this analysis, we repeated the analysis for women older than 59 with virtually the same results.

This is in contrast with the positive association between age at menopause and risk for CTS found by others (15).

Menopausal women who had their last menstrual period lless than one year ago were found to have a RR for CTS of 6.5 , while those with their last menstrual period 2 - 5 years ago had a statistically non-significant RR of 2.4. Possible explanations for these findings include:

1. a change in the endocrine status causes CTS;

2. women, who are only recently postmenopausal frequently have complaints which will cause them to consult their GP, so the chance that their CTS will be recognized as the cause of brachialgia will be greater.

Unlike earlier studies $(15,19)$, but in agreement with the findings of Cannon (17), we were unable to identify the use of oral contraceptives as a risk factor for CTS.

Our study confirms earlier findings (15) that a shorter stature, a greater weight or a higher Quetelet index are all associated with an increase of the RR for CTS. No other studies could be found to compare our results with.

We showed slimming courses to result in a RR of 2.1 for CTS, which had not been reported before in the literature. Our findings may point in the same direction as those from the study by Dieck and Kelsey, who demonstrated an odds ratio for CTS of 2.6 for women with a body weight of $80 \mathrm{kgs}$ or more (15). Such subjects are more likely to take slimming courses compared to persons with a lower body weight.

We demonstrated varicosis to have a RR of 12.0 in men and of 0.9 in women. Because others found a negative association of CTS with varicosis in women we think that the strong association we found between varicosis in men and CTS is merely coincidental. 
No association could be demonstrated between CTS and risk factors such as thyroid diseases in women, rheumatism or diabetes. This may be caused by the low prevalence of patients with these diseases in the general population. To show any correlation this study would have to be repeated in a population with a higher prevalence of these diseases.

\section{REFERENCES}

1. De Krom MCTFM, Knipschild PG, Kester ADM, Van der Lugt PJM, Thijs CT, Boekkooi PF. Carpal tunnel syndrome: The prevalence in the general population. This thesis, chapter 2.

2. Mumenthaler M. Der Schulter-Arm-Schmerz. Leitfaden für die Praxis. 2. Auflage. Bern-Stuttgart-Wien: Verlag Hans Huber, 1982:93-100.

3. Benini A. Das Karpal Tunnel Syndrom und die übrigen Kompressionssyndrome des Nervus Medianus. (Thieme Verlag 1975).

4. John V, Nau HE, Nahser HC, Reinhardt V, Venjakob K. CT of carpal tunnel syndrome. Am. J. Neuroradiol. 1983;4(3):770-772.

5. Kelsey JL. Epidemiology of musculoskeletal disorders. Monographs in epidemiology and biostatistics. Oxford University Press, New York, Oxford; 1982:168-19].

6. Spaans F. Compression and entrapment neuropathies. In: Handbook of clinical neurology. Vol 7(51):85-118 (Elseviers Science Publishers BV 1987).

7. Staal A. The entrapment neuropathies. In: Handbook of clinical neurology. Vol. 7(part I):285-325. (North Holland Publ. Cie, Amsterdam 1970).

8. Robbins $\mathrm{H}$. Anatomical study of the median nerve in the carpal tunnel and etiologies of the carpal-tunnel syndrome. J Bone and Joint Surg 1963;45A(5):953966.

9. Smith EM, Sonstegard DA, Anderson WH jr. Carpal tunnel syndrome: contribution of flexor tendons. Arch Phys Med Rehabil 1977;58(9):379-385.

10. De Krom MCTFM, Rensema JW, Lataster LMA, Drukker J. The connective tissue apparatus in the region of the carpal tunnel. In: Verh. Anat. Ges. 1987;81:335336. (VEB Gustav Fischer Verlag, Jena 1987).

11. Tanzer RC. The carpal tunnel syndrome, a clinical and anatomical study. J Bone Joint Surg. 1959;41A,4:626-634. 
12. Gelberman RH, Hergenroeder PT, Hargens AR, Lundborg GN, Akeson WH. The carpal tunnel syndrome. A study of carpal canal pressures. J Bone Joint Surg 1981;63A:380-383.

13. Lundborg GN, Gelberman RH, Minteer-Convery M, Lee YF, Hargens AR. Median nerve compression in the carpal tunnel - functional response to experimentally induced controlled pressure. J Hand Surg 1982;7:252-259.

14. Armstrong TJ, Chaffin DB. Carpal tunnel syndrome and selected personal attributes. J Occup Med 1979;21(7):481-486.

15. Dieck GS, Kelsey JL. An epidemiologic study of the carpal tunnel syndrome in an adult female population. Prev Med 1985;14:63-69.

16. Björkqvist S-E, Lang AH, Punnonen R, Rauramo L. Carpal tunnel syndrome in ovariectomized women. Acta Obstet Gynecol Scand 1977;56:127-130.

17. Cannon LJ, Bernacki EJ, Walter SD. Personal and occupational factors associated with carpal tunnel syndrome. JOM 1981;23(4):255-258.

18. Silverstein BA, Fine $\mathrm{LJ}$, Armstrong TJ. Occupational factors and carpal tunnel syndrome. Am J Industr Med 1987;11:343-358.

19. Sabour MS, Fadel HE. The carpal tunnel syndrome - a new complication ascribed to the "pill". Amer J Obstet Gynec 1971;107:1267. 


\section{CHAPTER 4}

CARPAL TUNNEL SYNDROME:

THE VALUE OF CLINICAL DIAGNOSTIC TESTS

M.C.T.F.M. de Krom, MD ${ }^{*}$, P.G. Knipschild, MD ${ }^{\#}$, A.D.M. Kester, PhD ${ }^{\&}$,F. Spaans, $\mathrm{MD}^{*}$, P.J.M. van der Lugt, $\mathrm{MD}^{*}$

Departments of ${ }^{*}$ Neurology, "Epidemiology and Health Care Research, ${ }^{*}$ Medical Informatics and Statistics, ${ }^{+}$Clinical Neurophysiology, University Hospital Maastricht, University of Limburg, Maastricht, the Netherlands.

\section{ABSTRACT}

In people who are suspected of having carpal tunnel syndrome (CTS) it is common practice to ask about flick sign and to extend physical examination by many CTS related clinical diagnostic tests. Examples of these are examination of thenar muscles, wrist extension test and wrist flexion (Phalen's) test, tourniquet test, Tinel's sign, pressure on the exit of the carpal tunnel, Lüthy"s sign and sensibility examination. We studied the validity of these tests in people who reported waking up because of nocturnal brachialgia.

In an age and sex stratified random sample of 504 subjects from the general population, 50 persons who woke up because of nocturnal brachialgila could be identified. They were tested and had a subsequent neurophysiological examination, which was abnormal in 28 subjects and normal in the remaining 22 . Among these 50 persons, nocturnal brachialgia was reported in 93 hands. In $44(47 \%)$ the presence of CTS could be established by neurophysiological examination.

All clinical diagnostic tests turned out to have a low validity, with iotas ranging from -0.16 to +0.19 . Posterior probability of CTS ranged from 35 to 70 per cent for positive test results and from 41 to 62 per cent for negative test results. Even a combination of three tests with relatively high validity (abductor pollicis brevis muscle paresis, hyperpathy and flick sign) did not change the probability of CTS to a any relevant extent.

We conclude that the clinical diagnostic tests considered do not contribute to the differential diagnosis of CTS in patients with nocturnal brachialgia. 


\section{INTRODUCTION}

Patients do not consult their doctor because of a particular disease, but because they have one or more complaints. These are translated by the doctor into a working hypothesis with a certain probability. Further history taking and physical examination are intended to change this prior probability into posterior probabilities, which are so low (negative test results) that the presence of this disease is excluded, or so high (positive tests results) that disease intervention may be considered.

Many simple clinical diagnostic tests have been designed on the basis of biological plausibility and clinical experience. However, it is sometimes not clear whether these tests contributé tó the differential diagnosis underlying a certain complaint. It is especially when discrimination is sought in a quantitative sense that empirical studies to validate the use of these tests are often lacking.

A great number of tests has been advocated for the diagnosis of carpal tunnel syndrome (CTS) (1-11). Patients with this disorder complain of paraesthesiae, numbness and/or pain involving the median nerve innervated fingers, which in most cases awake them at night. In an earlier study (this thesis, chapter 2) we demonstrated that nearly half of the patients who wake up due to this nocturnal brachialgia, have a CTS according to our criteria.

In this paper we question the validity of known CTS related provocative tests, on the basis of a population study.

\section{METHODS}

\section{A. Patients}

The study was done in Maastricht, the Netherlands, and some surrounding villages. An age and sex stratified random sample was drawn from the adult general population, including twice as many women as men. Out of 715 eligible subjects 504 (164 men and 340 women) were willing to be interviewed. Three of these had recently been operated upon for CTS. The remaining 501 were asked, among other things: "Do you wake up at night because of tingling, pain and/or numbness in your fingers?". Seventy persons answered this question in the affirmative and were invited for further testing. Of these, 15 refused further co-operation. The other 55 subjects were interviewed for the second time. Five of them now reported that their complaints had disappeared. The other 50 subjects with nocturnal brachialgia were the study population.

\section{B. Clinical diagnostic tests}

All patients were examined by a neurologist with special experience in patients with brachialgia and CTS (MdK) at the out-patient department of neurology at the University Hospital Maastricht. Testing was done without knowledge of the neurophysio- 
logical examination results. Tests were scored positive or negative for CTS only for the hand about which the patient complained. The following clinical diagnostic tests were performed:

1. flick sign: the patient is asked if flicking movements with wrist and fingers eliminate the complaints in the hand (10);

2. thenar wasting: inspection of the hand for thenar atrophy;

3. paresis abductor pollicis brevis muscle: the strength of this muscle is estimated manually;

4. paresis opponens pollicis muscle: the strength of this muscle is estimated manually;

5. wrist extension test: the patient is asked to keep both hands with the wrist in complete dorsal extension for one minute. If numbness and/or tingling are produced or exaggerated in the median nerve distribution of the hand within 60 seconds, the test is considered positive (6);

6. Phalen's test or wrist flexion test: the patient is asked to keep both hands with the wrist in complete palmar flexion for one minute. The test is scored as sub 5(8);

7. tourniquet test: a pneumatic blood pressure cuff, placed proximal to the elbow is inflated to above the patient's systolic pressure. (In their original article Gilliat and Wilson did not indicate to what level the pressure in the cuff should be raised.) The test is scored as sub 5 (3);

8. Tinel's sign: finger percussion of the median nerve at the passage under the flexor retinaculum. If tingling in the median nerve innervated area is produced, the test is considered positive $(2,12,13,14)$;

9. pressure test: if pressure of the investigator's thumb on the place where the median nerve leaves the carpal tunnel causes pain, the test is scored positive (7);

10. Lüthy's sign: if paresis of thumb abduction means that the skinfold between thumb and index-finger does not close tightly around a bottle or cup, this test is considered positive (5);

11. hypoalgesia: if testing of the sensibility by means of a sharp pinned wheel results in a diminished sensation in the median nerve area this test is scored positive. This procedure is started in the radial or ulnar nerve innervated area and subsequently compared with sensibility in the median nerve area;

12. hyperpathy: testing of the sensibility as sub 11 ; the test is scored positive in case of hyperpathy in the median nerve area.

\section{Nerve conduction studies and gold standard}

Details of the neurophysiological examination methods have been presented in chapter 1 . We decided to take as our gold standard for CTS a combination of the typical history (i.e. paraesthesiae, numbness and/or pain in the median nerve innervated fingers with a frequency of twice a week or more, which in most cases wakes up the patient) and abnormal nerve conduction of the median nerve at the wrist. Neurographic signs of polyneuropathy should be absent. 


\section{STATISTICAL ANALYSIS}

In statistical analyses of the relation between clinical diagnostic tests and the gold standard, one astually considers both hands of a person to be independent, i.e. statistical testing is done as if there are $2 n$ cases, when persons are involved. This implies the assumption that the probability of a left-sided CTS is the same whether or not a right-sided CTS is present, given the clinical diagnostic tests.

In this study we found, using a multiple logistic model to take account of the diagnostic signs, that the probability of a left-sided CTS was more than ten times higher when a right-sided CTS was present. Thus, the independence assumption is not valid.

Therefore, all test results were compared with the gold standard using $\mathrm{X}^{2}$-tests separately for the left and right hand.

Next we calculated the iota for the diagnostic validity of each test, i.e. the observed validity minus chance validity, divided by one minus chance validity (15). These calculations were made using the combined data for both hands. Sensitivity and specificity were not calculated, because these depend strongly on the prevalence of, respectively, positive and negative test results. Of more interest are the posterior probabilities for positive and negative test results. These were also calculated using the combined data for both hands. Finally, the probability changes were studied for a combination of the tests with the highest validities.

\section{RESULTS}

The 50 subjects ( 7 men, 43 women) examined were found to have nocturnal brachialgia in 44 right hands and 49 left hands. Twenty-eight (one man, 27 women) of these 50 subjects turned out to have CTS in 44 hands, i.e. 47 per cent of 93 hands (9 on the right side only, 3 on the left side only, and 16 on both sides). Increased median nerve DML was found in 20 out of 93 hands with nocturnal brachialgia. Delayed distal sensory conduction of the median nerve was found in 44 out of these 93 hands. Increased DML or slowing of nerve conduction in the segments wrist-digit II and wristdigit III did not occur without delayed conduction in the median nerve fibres to digit IV (or absent SNAPs digit IV). In fact, slowing was usually most pronounced in these filores.

Only three of the ten hands (of nine patients) which showed a slight thenar atrophy had increased DMLs and/or decreased CMAP amplitudes. Of the remaining six subjects, four showed only minimal to mild increase of difference in distall sensory latency (deltaDSL) between the median and ulnar nerve as recorded at the ring-finger after stimulation proximal of the carpal ligament, one patient was found to have thenar atrophy in the hand opposite the one with CTS, and one patient had completely normal nerve conduction studies. 
Table 1 shows the data for each clinical diagnostic test. The validity of the various tests was low, with many false positive and false negative test results. Six out of 12 even had negative iotas, which indicates complete invalidity. The other six were not much better. The highest iotas were found for testing the paresis of the abductor pollicis brevis muscle $(+0.19)$, Lüthy's sign $(+0.17)$, hyperpathy $(+0.15)$ and flick sign $(+0.11)$. The general impression is that all iotas are close to zero (no validity beyond chance validity) with some chance dispersion.

The right part of table 1 shows the consequences at a prior probability of 47 per cent. With a positive test result this probability changed to $35-70$ per cent, while with a nega-

Table 1. Results of various tests for CTS studied in 93 hands with nocturnal brachialgia (44 left and 49 right hands, 50 patients)

\begin{tabular}{|c|c|c|c|c|c|c|c|c|c|}
\hline & & $\begin{array}{l}\operatorname{CTS} L \\
\text { yes } \\
n=19\end{array}$ & $\begin{array}{l}\text { CTS L } \\
\text { no } \\
n=25\end{array}$ & $\begin{array}{l}\text { CTS R } \\
\text { yes } \\
n=25\end{array}$ & $\begin{array}{l}\text { CTS } \\
\text { no } \\
n=2\end{array}$ & $R$ iota & $\begin{array}{l}\text { prior } \\
\text { proba- } \\
\text { bility }\end{array}$ & $\begin{array}{l}\text { post. } \\
\text { proba- } \\
\text { bility } \\
\mathrm{T}^{+}\end{array}$ & $\begin{array}{l}\text { posi. } \\
\text { proba- } \\
\text { bility } \\
\mathrm{T}^{-}\end{array}$ \\
\hline \multirow[t]{2}{*}{ 1. flick sign } & pos. & 9 & 10 & 13 & 9 & +0.11 & $47 \%$ & $54 \%$ & $42 \%$ \\
\hline & neg. & 10 & 15 & 12 & 15 & & & & \\
\hline \multirow[t]{2}{*}{ 2. thenar wasting } & pos. & $5^{*}$ & 2 & 2 & 1 & +0.10 & $47 \%$ & $70 \%$ & $45 \%$ \\
\hline & neg. & 14 & 23 & 23 & 23 & & & & \\
\hline \multirow{2}{*}{$\begin{array}{l}\text { 3. paresis abductor } \\
\text { pollicis brevis }\end{array}$} & pos. & 7 & 5 & 10 & 5 & +0.19 & $47 \%$ & $63 \%$ & $41 \%$ \\
\hline & neg. & 12 & 20 & 15 & 19 & & & & \\
\hline \multirow{2}{*}{$\begin{array}{l}\text { 4. paresis opponens } \\
\text { pollicis }\end{array}$} & pos. & 2 & 6 & 3 & 1 & -0.03 & $47 \%$ & $42 \%$ & $48 \%$ \\
\hline & neg. & 17 & 19 & 22 & 23 & & & & \\
\hline \multirow{2}{*}{$\begin{array}{l}\text { 5. wrist extension } \\
\text { test }\end{array}$} & pos. & 8 & 11 & 10 & 11 & -0.04 & $47 \%$ & $45 \%$ & $49 \%$ \\
\hline & neg. & 11 & 14 & 15 & 13 & & & & \\
\hline \multirow{2}{*}{$\begin{array}{l}\text { 6. wrist flexion test** } \\
\text { (Phalen's test) }\end{array}$} & pos. & 10 & 10 & 11 & 12 & +0.01 & $48 \%$ & $49 \%$ & $48 \%$ \\
\hline & neg. & 9 & 14 & 14 & 11 & & & & \\
\hline \multirow[t]{2}{*}{ 7. tourniquet test* } & pos. & 13 & 21 & 18 & 18 & -0.12 & $48 \%$ & $44 \%$ & $62 \%$ \\
\hline & neg. & 6 & 3 & 7 & 5 & & & & \\
\hline \multirow[t]{2}{*}{ 8. Tinel's sign } & pos. & 4 & 12 & 7 & 8 & -0.16 & $47 \%$ & $35 \%$ & $53 \%$ \\
\hline & neg. & 15 & 13 & 18 & 16 & & & & \\
\hline \multirow{2}{*}{$\begin{array}{l}\text { 9. pressure exit } \\
\text { carpal tunnel }\end{array}$} & pos. & 0 & 2 & 2 & 1 & -0.02 & $47 \%$ & $40 \%$ & $48 \%$ \\
\hline & neg. & 19 & 23 & 23 & 23 & & & & \\
\hline \multirow[t]{2}{*}{ 10. Lüthy"s sign } & pos. & 8 & 7 & 11 & 6 & +0.17 & $47 \%$ & $61 \%$ & $41 \%$ \\
\hline & neg. & 11 & 18 & 14 & 18 & & & & \\
\hline \multirow{2}{*}{$\begin{array}{l}\text { 11. hypoalgesia median } \\
\text { nerve area test }\end{array}$} & pos. & 5 & 9 & 12 & 11 & -0.02 & $47 \%$ & $46 \%$ & $48 \%$ \\
\hline & neg. & 14 & 16 & 13 & 13 & & & & \\
\hline \multirow{2}{*}{$\begin{array}{l}\text { 12. hyperpathy median } \\
\text { nerve area test }\end{array}$} & pos. & $6^{*}$ & 2 & 5 & 3 & +0.15 & $47 \%$ & $69 \%$ & $43 \%$ \\
\hline & neg. & 13 & 23 & 20 & 21 & & & & \\
\hline
\end{tabular}

* $p<0.05\left(\mathrm{X}^{2}\right.$-test $)$

* * this test was omitted in one woman 
Table 2. Results of a combination of three tests for CTS studied in 93 hands with nocturnal brachialgia (50 patients)

\begin{tabular}{l|cccc|ccc|c}
\hline paresis abductor & pos & pos & pos & neg & pos & neg & neg & neg \\
hyperpathy & pos & pos & neg & pos & neg & pos & neg & neg \\
flick sign & pos & neg & pos & pos & neg & neg & pos & neg \\
\hline CTS present & 1 & 4 & 6 & 4 & 6 & 2 & 11 & 10 \\
CTS absent & 1 & 0 & 1 & 4 & 8 & 0 & 13 & 22 \\
\hline posterior probability & & & $71 \%$ & & & $48 \%$ & & $31 \%$ \\
\hline
\end{tabular}

tive test result it changed to 41-62 per cent. Again, the general impression is that none of the tests changes the prior probability to a clinically relevant posterior probability, and that all small changes may be due to chance. Statistical significance at 0.05 level was reached in only two of the 24 tests. Both concerned left hands, with inconclusive results for the right hands.

Next, we considered a combination of tests with the highest iotas. Since Lüthy's sign is strongly related to abductor pollicis brevis muscle strength, we selected only abductor pollicis brevis muscle paresis in combination with hyperpathy and flick sign. Table 2 shows the data. At least two of the three tests were positive for 21 hands, of which 15 $(=71 \%)$ had CTS. In 32 hands all three tests were negative, although there were 10 $(=31 \%)$ CTS diagnoses. It is clear then, that the prior probability of 47 per cent does not change enough to have policy consequences for the patient with nocturnal brachialgia. A neurophysiological examination is still necessary to decide whether CTS is present or not.

\section{Discussion}

In clinical research into the efficacy of a new drug it is an accepted view that research goes through a number of phases. The same should be advocated for clinical diagnostic tests (1.6). Such a study should start with establishing the sensitivity of a test among severely diseased people. The proportion of positive test results can then be compared with one minus the specificity, i.e. the number of false positive test results among completely healthy individuals. If this phase 1 research reveals promising data, it makes sense to enlarge the disease spectrum (phase 2) and compare the different sensitivities with one minus the specificity among pseudo-diseased subjects (phase 3 ). The real value of the test can only be assessed in a clinical practice situation (phase 4): patients with signs and symptoms indicative of the disease are subjected to the new test and their results are compared with those of the gold standard. 
Various medical textbooks advocate the use of provocative tests in the differential diagnosis of patients with nocturnal brachialgia $(6,7,17,18)$. Empirical studies conducted so far to support this view are limited in quality. We feel that uncontrolled studies $(5,8,9,11)$ and studies in which only some of the cases had their CTS neurophysiologically confirmed $(3,19,20)$ are not informative. Five studies have been published in which all controls $(1,2,21,22)$ or most of them (23) were free of nocturnal brachialgia. Their results were sometimes promising for the diagnostic value of certain provocative tests $(1,2,22)$, or sometimes not $(21,23)$. However, it is too early to advocate or reject the use of these tests, when phase 3 and 4 studies have not been performed yet. Their results may be even misleading, especially when a test has a higher sensitivity for the detection of other causes of nocturnal brachialgia than for CTS. The net effect is then that a positive test result decreases the probability of CTS (compare our results on the tourniquet test with those of the inventor (3)).

Case-control studies with healthy controls (i.e. without paraesthesiae) must be followed by studies using a population of patients suffering from nocturnal brachialgia. In these studies the cases group should consist of patients with abnormal neurophysiological findings, whereas the others may be considered to be controls. In the literature we found one case-control and three cross-sectional studies with this design $(10,13,14,24)$.

Pryse-Phillips found the flick sign to be present in 93 per cent of 212 subjects with CTS, compared to four per cent of 184 subjects with paraesthesiae due to other causes (10). Iota for the diagnostic validity was +0.88 in this study, with much discriminative power at a prior probability of approximately 50 per cent.

Aebi-Ochsner compared the results of eight tests (thenar wasting, pressure exit carpal tunnel, Lüthy's sign, paresis opponens pollicis muscle, hyperpathy and hypoalgesia median nerve area, Phalen's test, wrist extension test) for 132 hands of 84 subjects, clinically suspected to have CTS. Of these, 80 hands were found to have abnormal results at the neurophysiological examination and 52 were not. She concluded that there was no single sign, nor a combination of signs, which proved to be a clinically relevant indicator of CTS in these patients, with the exception of thenar wasting (24).

Golding et al studied five clinical diagnostic tests for carpal tunnel syndrome in 70 subjects with acroparaesthesiae. Eventually, of the 117 hands tested, 49 were diagnosed as CTS. None of the tests used (median nerve hypoalgesia, thenar wasting, Phalen's test, Tinel's sign, tourniquet test', nor combinations of several of these tests, were found to be useful in diagnosing CTS (13).

Heller et al considered 60 subjects and 80 hands with brachialgia, 58 of which were diagnosed as CTS. Neither Phalen's test nor Tinel's sign proved to be valid clinical tests for CTS (14).

In general, our results are consistent with those of other clinically relevant studies on nine provocative tests $(13,14,24)$. We were the first to demonstrate a low validity for abductor paresis. As for the flick sign, the validity we found was much lower than in the study by Pryse-Phillips (10). This inconsistency may be due to several shortcomings in the study: overrepresentation of severe cases of CTS, lack of blinding and referral bias. 
Our "negatiwe" result on thenar wasting is consistent with that of Golding et al (13), but not with the report by Aebi-Ochsner (24). Generally, it can be assumed that the validity of the thenar wasting sign depends strongly on the stage of CTS.

We feel that there is no longer a place for provocative tests in the diagnostic procedure for CTS. They are found not to discriminate between CTS and other causes of nocturnal brachialgia to the extent that neurophysiological examination may be regarded as unnecessary. The probability of CTS does not change if, for instance, the wrist extension test produces tingling, nor if it does not. The diagnostic value of other provocative tests is just as questionable. Even a combination of tests with (relatively!) high validities cannot exclude or confirm CTS to a substantial extent.

Therefore it is better to refer patients with nocturnal brachialgia for proper neurophysiological examination than to burden them with the above mentioned clinical diagnostic tests, of which we demonstrated the unreliable relation with CTS.

\section{REFERENCES}

1. Bowles AP, Asher SW, Pickett JB. Use of Tinel's sign in CTS. Ann Neurol $1983 ; 13(6): 689-690$.

2. Gellman H, Gelberman RH, Tan AM, Botte MJ. Carpal tunnel syndrome. An evaIuation of the provocative diagnostic tests. J Bone Joint Surg 1986;68A(5):735-737.

3. Gilliat RW, Wilson TG. A pneumatic tourniquet test in the CTS. Lancet 1953;595597.

4. Heywood PL. Through the carpal tunnel. BMJ 1987;294:660-661.

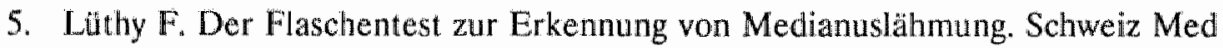
Wschr 1962;92:1573-1574.

6. Mumenthaler M, Schliack H. Läsionen peripherer Nerven. Diagnostik und Therapie. 5. Auflage. Stuttgart, New York: Georg Thieme Verlag, 1987:243-262.

7. Mumenthaler M. Der Schulter-Arm-Schmerz. Leitfaden für die Praxis. 2. Auflage. Bern-Stuttgart-Wien: Verlag Hans Huber, 1982:93-100.

8. Phalen GS, Kendrick, JI. Compression Neuropathy of the median nerve in the carpal tunnel. JAMA 1957;164(5):524-530.

9. Phalen GS. Reflections on 21 years'experience with the carpal tunnel syndrome. JAMA 1970;212(8):1365-1367. 
10. Pryse-Phillips WEM. Validation of a diagnostic sign in carpal tunnel syndrome. J Neurol Neurosurg Psychiat 1984;47:870-872.

11. Szabo RM, Gelberman RH, Dimick MP. Sensibility testing in patients with carpal tunnell syndrome. J Bone Joint Surg 1984;66A(1):60-64.

12. Tinel J. Le signe du "fourmillement" dans les lesions des nerfs peripheriques. Presse Med 1915;23:388-389

13. Golding DN, Rose DM, Selvarajah K Clinical tests for carpal tunnel syndrome: an evaluation. Br J Rheumatol 1986;25:388-390.

14. Heller L, Ring H, Costeff H, Solzi P. Evaluation of Tinel's and Phalen's signs in diagnosis of the carpal tunnel syndrome. Eur Neurol 1986;25:40-42.

15. Knipschild P. Looking for gall-bladder disease in the patient's iris. BMJ 1988;297:1578-1581.

16. Feinstein AR. Improvements of architecture in diagnostic marker research. In: Feinstein AR, ed. Clinical epidemiology. Philadelphia: WB Saunders, 1985:623624.

17. Benini A. Das Karpal Tunnel Syndrom und die übrigen Kompressionssyndrome des Nervus Medianus. Stuttgart: Thieme Verlag, 1975.

18. Walton J. Brain's diseases of the nervous system. 9th ed. Oxford, New York, Tokyo: Oxford University Press, 1985:505.

19. Kendall D. Aetiolology, diagnosis and treatment of paraesthesiae in the hands. BMJ 1960;1633-1640.

20. Loong SC. The carpal tunnel syndrome: a clinical and electrophysiological study of 250 patients. Proc Aust Assoc Neurol 1977;14:51-65.

21. Stewart JD, Eisen A. Tinel"s sign and the carpal tunnel syndrome. BMJ 1978;11251126.

22. Mossman SS, Blau JN. Tinel's sign and the carpal tunnel syndrome. BMJ 1987;294:680.

23. Gelmers HJ. The significance of Tinel's sign in the diagnosis of carpal tunnel syndrome. Acta Neurochir 1979;49:255-258. 
24. Aebi-Oehsner C, Ludin HP. Das Karpaltunnelsyndrom - klinische Symptomatologie und Electrophysiologische Befunde. Fortschr Neurol Psychiatr 1979;47(6):307319. 
CARPAL TUNNEL SYNDROME:

PROGNOSTIC INDICATORS OF SURGICAL SUCCESS

M.C.T.F.M. de Krom, MD ${ }^{*}$, A.D.M. Kester, PhD ${ }^{\&}$, P.G. Knipschild, MD ${ }^{\#}$, F. Spaans, $\mathrm{MD}^{+}$, A.C.J. Slooff, $\mathrm{MD}^{\$}$ and P.J.M. van der Lugt, MD

Departments of ${ }^{*}$ Neurology, ${ }^{\text {\& }}$ Medical Informatics and Statistics, ${ }^{\#}$ Epidemiology and Health Care Research, ${ }^{+}$Clinical Neurophysiology, University Hospital Maastricht, University of Limburg, Maastricht, The Netherlands. Department of "Neurosurgery, De Wever Hospital, Heerlen, The Netherlands.

\section{ABSTRACT}

Surgical treatment of carpal tunnel syndrome (CTS) has a high success rate. Most investigators have been unable to find a relation between surgical success and preoperative findings.

Using advanced statistical techniques, we studied surgical success rate in relation to preoperative items like age, sex, hand operated upon, hand dominance, duration and frequency of preoperative complaints and preoperative neurophysiological findings. One hundred and twenty patients operated upon for CTS were interviewed, usually on the day of their CTS operation. At least six months after the operation a second questionnaire, concerning the same CTS complaints, was completed.

Of all patients 59 per cent were now symptom-free, 32 per cent reported a decrease in their complaints and nine per cent had no change or increased complaints.

After multiple logistic regression analyses we found higher success rates in patients with more severely disturbed sensory nerve conduction velocities of the median nerve at the wrist, in younger patients, in lefthanded patients who have been operated upon for a leftsided CTS and in patients who had daily complaints prior to operation. On the basis of these findings we suggest further research into the efficacy of surgical treatment compared to that of conservative measures in older CTS patients with less severely disturbed median nerve conduction velocities. 


\section{INTRODUCTION}

Surgicall rellease of the median nerve by dividing the transverse carpal ligament is a highly successful treatment of carpal tunnel syndrome (CTS) (1-17).

Most investigators have not been able to demonstrate a clear relation between surgical success rate and various preoperative findings. In elderly people, however, it was our experience that the success rate was lower than might be expected from the literature. Moreover, we felt that a new study in the Netherlands, using advanced statistical methods, would be useful. For that reason we studied surgically treated patients to discover the relation between various preoperative prognostic indicators, such as age, sex, hand operated upon, hand dominance, duration and frequency of preoperative complaints, and neurophysiological findings on the one hand, and the reported postoperative results of carpal tunnel surgery on the other.

\section{METHODS}

Patients were a series of consecutive patients from the out-patient department of neurology at the University Hospital Maastricht, the Netherlands. CTS diagnosis was made by one of the seven neurologists on the basis of clinical history and neurophysiological findings. (See chapter 1 for details of the neurophysiological examination methods.) We decided to take as our gold standard for CTS a combination of the typical history (i.e. paraesthesiae, numbness and/or pain in the median nerve innervated fingers with a frequency of twice a week or more, which in most cases wakes up the patient) and abnormal nerve conduction of the median nerve at the wrist. Neurographic signs of polyneuropathy should be absent.

\section{SURGICAL TECHNIQUE}

All surgical procedures were performed on an out-patient basis, under regional anaesthesia using a pneumatic tourniquet. A skin incision was made, in line with the third finger in the palm, between the thenar and hypothenar eminences. The palmar fascia was cleaved longitudinally, after which the carpal ligament was divided completely, splitting the roof of the carpal tunnel. The median nerve with its divisions, including the motor branch and surroundings were inspected. Sometimes a definite impression was found or an increased amount of connective tissue. An external neurolysis was performed only when the epineurium was found to be thickened. Skin was 
closed in one single layer. A pressure dressing (applied immediately after operation and release of the tourniquet) was removed on day 4 after the operation. Stitches were removed on day 12 after the operation.

\section{QUESTIONNAIRES}

All patients were asked if they were willing to have an extensive, standardized questionnaire, administered by a trained interviewer, usually on the day of the operation. Questions included, among other things, complaints of nocturnal pain, numbness or pins and needles in the fingers, their frequency and duration, hand dominance.

A second, postal questionnaire was sent to all patients not earlier than six months after the operation. This questionnaire was much shorter than the first one, asked only about persisting CTS complaints and had to be completed by the patients themselves. Complaints were graded as disappeared, decreased, unchanged or increased. If persistent CTS complaints were reported, the patient was invited to the hospital for a physical examination by one of us (MdK) and for a new neurophysiological examination like the one which had been performed before the operation by another author (FS). The doctor who did the physical examination was blind for the results of the neurophysiological examination.

\section{STATISTICAL ANALYSIS}

The success of the operation was judged from the changes in complaints of the patient. Since only seven and four patients scored in, respectively, the categories "unchanged" and "increased", these have been taken together in the analysis. The relation between each prognostic variable and the outcome is given below in $2 \times 3$ tables for the dichotomous variables sex, CTS side, hand dominance, contralateral CTS and frequency of complaints. The continuous variables age, duration of complaints and difference in sensory latency (deltaDSL) between median and ulnar nerves as recorded at the ring-finger were trichotomized into approximately equal categories. In the preoperative neurophysiological examination, sensory nerve action potentials of the median nerve to digit II, III and IV could frequently not be elicited. In these cases deltaDSL. was set at five milliseconds for the analysis. In the three ambidexterous patients, the hand operated upon was considered to be dominant.

To assess the relation between several prognostic indicators and outcome, multiple logistic regression was used, taking continuation ratio logits as the dependent variable $(18,19)$. The model and its result are explained more fully in the appendix. It allows estimation of success probabilities for virtually any combination of prognostic variables. For the sake of simplicity, we present the results as estimated probabilities of having 
Table 1. Relation of the follow-up time with the success rate of CTS operation among 120 hands of 120 patients

\begin{tabular}{lcccc}
\hline & & $\begin{array}{l}\text { complaints } \\
\text { disappeared }\end{array}$ & $\begin{array}{l}\text { complaints } \\
\text { decreased }\end{array}$ & $\begin{array}{l}\text { complaints } \\
\text { unchanged/ } \\
\text { increased } \\
\mathrm{n}=11(\%)\end{array}$ \\
\hline follow-up & $\mathrm{n}=71(\%)$ & $\mathrm{n}=38(\%)$ & $4(10)$ \\
(days) & $365-364$ & $25(61)$ & $12(29)$ & $4(8)$ \\
& $730-924$ & $34(67)$ & $13(25)$ & $4(11)$ \\
\hline
\end{tabular}

Table 2. Relation of various prognostic indicators with the success rate of CTS operation

\begin{tabular}{|c|c|c|c|c|c|}
\hline $\begin{array}{l}\text { prognostic } \\
\text { indicator }\end{array}$ & & $\begin{array}{l}\text { complaints } \\
\text { disappeared } \\
n=71(\%)\end{array}$ & $\begin{array}{l}\begin{array}{c}\text { complaints } \\
\text { decreased }\end{array} \\
\mathrm{n}=38(\%)\end{array}$ & $\begin{array}{r}\text { com } \\
\text { unch } \\
\text { incr } \\
\mathrm{n}=\end{array}$ & $\begin{array}{l}\text { laints } \\
\text { anged/ } \\
\text { eased } \\
11(\%)\end{array}$ \\
\hline sex & $\begin{array}{l}\text { male } \\
\text { female }\end{array}$ & $\begin{array}{l}13(56) \\
58(60)\end{array}$ & $\begin{array}{r}7(30) \\
31(32)\end{array}$ & $\begin{array}{l}3 \\
8\end{array}$ & $\begin{array}{l}(13) \\
(8)\end{array}$ \\
\hline age (years) & $\begin{array}{l}22-39 \\
40-49 \\
50-75\end{array}$ & $\begin{array}{l}22(61) \\
22(56) \\
27(60)\end{array}$ & $\begin{array}{l}14(39) \\
11(28) \\
13(29)\end{array}$ & $\begin{array}{l}0 \\
6 \\
5\end{array}$ & $\begin{array}{l}(0) \\
(15) \\
(11)\end{array}$ \\
\hline hand operated upon* & $\begin{array}{l}\text { left } \\
\text { right }\end{array}$ & $\begin{array}{l}27(69) \\
44(54)\end{array}$ & $\begin{array}{l}11(28) \\
27(33)\end{array}$ & $\begin{array}{r}1 \\
10\end{array}$ & $\begin{array}{l}(2) \\
(12)\end{array}$ \\
\hline hand operated upon & $\begin{array}{l}\text { dominant } \\
\text { non-dom. }\end{array}$ & $\begin{array}{l}54(61) \\
17(55)\end{array}$ & $\begin{array}{l}26(29) \\
12(39)\end{array}$ & $\begin{array}{l}9 \\
2\end{array}$ & $\begin{array}{l}(10) \\
(6)\end{array}$ \\
\hline $\begin{array}{l}\text { other hand also operated } \\
\text { upon for CTS }\end{array}$ & $\begin{array}{l}\text { no } \\
\text { yes }\end{array}$ & $\begin{array}{l}47(57) \\
24(65)\end{array}$ & $\begin{array}{l}26(31) \\
12(32)\end{array}$ & $\begin{array}{r}10 \\
1\end{array}$ & $\begin{array}{l}(12) \\
(3)\end{array}$ \\
\hline $\begin{array}{l}\text { duration of complaints } \\
\text { (years) }\end{array}$ & $\begin{array}{l}\leq 1 \\
2-4 \\
5-30 \\
\text { unknown }\end{array}$ & $\begin{array}{l}12(67) \\
20(50) \\
17(57) \\
22(69)\end{array}$ & $\begin{array}{r}5(28) \\
13(32) \\
11(37) \\
9(28)\end{array}$ & $\begin{array}{l}1 \\
7 \\
2 \\
1\end{array}$ & $\begin{array}{l}(6) \\
(18) \\
(7) \\
(3)\end{array}$ \\
\hline frequency of complaints & $\begin{array}{l}\text { 2-3/week } \\
\text { daily }\end{array}$ & $\begin{array}{l}14(78) \\
57(56)\end{array}$ & $\begin{array}{r}2(11) \\
36(35)\end{array}$ & $\begin{array}{l}2 \\
9\end{array}$ & $\begin{array}{l}(11) \\
(9)\end{array}$ \\
\hline deltaDSL** (msec) & $\begin{array}{l}0.5-1.4 \\
1.5-4.9 \\
\infty \\
\end{array}$ & $\begin{array}{l}17(44) \\
30(60) \\
24(77) \\
\end{array}$ & $\begin{array}{r}18(46) \\
15(30) \\
5(16)\end{array}$ & $\begin{array}{l}4 \\
5 \\
2\end{array}$ & $\begin{array}{l}(10) \\
(10) \\
(6) \\
\end{array}$ \\
\hline
\end{tabular}

$p=0.054\left(\mathrm{X}^{2}\right.$ test $)$

$* * p=0.005\left(X^{2}\right.$ test $) /$ deltaDSL is the difference in distal sensory latency between the median and ulnar nerve as recorded at the ring-finger after stimulation proximal of the carpal ligament. 
complaints "at least decreased" or "disappeared", for some of the more prevalent combinations of prognostic indicators. The relations with age and deltaDSL are given as graphs.

\section{RESULTS}

Out of 180 eligible consecutive CTS patients 128 ( 24 men and 104 women) were willing to have the first standardized questionnaire. One hundred and fourteen (18 men, 96 women, i.e. $89 \%$ ) reported pain, 127 ( 24 men, 103 women, i.e. $99 \%$ ) tingling and 113 ( 18 men, 95 women, i.e. $88 \%)$ numbness in their fingers. At least one of these complaints was found in all 128 CTS patients. One hundred and twenty-two woke up at night because (of one) of these complaints. So, 95\% of all CTS patients had at least one of these complaints, which woke them up.

The second questionnaire was sent to the same 128 CTS patients. Two patients were found to be deceased, five were not willing to co-operate and 121 returned the questionnaire. One form had not been completed intelligibly, so 120 could be studied. These concerned 23 men (mean age 47 (range 26-75) years) and 97 women (mean age 47 (range 22-75) years), with 39 CTS operations on the left side and 81 on the right side.

Seventy-one patients ( $59 \%$ ) reported that their CTS complaints had disappeared, $38(32 \%)$ reported that their complaints had decreased, while $11(9 \%)$ reported unchanged or increased complaints. The 120 patients had follow-up periods ranging from 200-924 days. Table 1 gives the success rate for different follow-up periods. No association could be demonstrated, and so the results after different follow-up periods were taken together in the univariate analysis.

Table 2 shows the results for the prognostic indicators. For each category of an indicator the table presents the success rate of the operation, i.e. the changes in complaints. The duration of the complaints before the operation could be remembered by 88 patients only. In this univariate analysis, no relation was found between the success rate and sex, age, hand dominance, other hand also operated upon and duration of complaints. The success rate appeared to be higher for patients with more frequent complaints, but this relation was not statistically significant. The deltaDSL was found to be associated with the success rate: the higher the deltaDSL, the better the result. Moreover, left hand operations tended to be more successful than operations on the right hand.

In the multiple logistic model, age, dominance of the hand operated upon and frequency of the complaints also turned out to be predictive of the success rate, apart from the relations found earlier, viz. with deltaDSL and side of the operation. In Table 3 we present some examples.

Figure 1 shows the estimated relation between surgical success rates and deltaDSL. As an example we focussed on fifty year old patients, who had an operation of the right, dominant hand, and who suffered from daily complaints preoperatively. According to Table 3 changing these conditions moves the curves up or down. A higher value for deltaDSL was clearly associated with better surgical results. 
Table 3. Estimated success rates of CTS operation from the logistic regression model (see appendix)

\begin{tabular}{|c|c|}
\hline complaints & $\begin{array}{l}\text { complaints } \\
\text { disappeared }\end{array}$ \\
\hline$\%$ & $\%$ \\
\hline
\end{tabular}

a) 50 yrs old, right dominant hand, daily complaints; deltaDSL $=2.5 \mathrm{msec}$

b) as a) but left dominant hand

c) as a) but complaints $2-3$ times/week

d) as a) but right non-dominant

e) as a) but left non-dominant

90

Similar curves are given in Figure 2 to depict the relation between postoperative complaints and age. Again we took hypothetical patients having the same characteristics as mentioned above, except for a deltaDSL of 2.5 milliseconds, and ages between 22 and 75 years. At older age the probability of at least a decrease in complaints declined substantially. The rate of complete cure, however, appeared to be about 55 per cent, independent of age.

In the second questionnaire 11 out of 120 CTS patients who had been operated upon reported persisting complaints. Of these 11 patients, one woman reported complaints of a snapping finger of the hand operated upon for CTS. She was not tested any further. Of the other ten patients six were willing to have a physical examination and a new nerve conduction test. Two reported not waking up due to their complaints anymore. The remaining four patients continued to wake up at night due to their complaints. Two of them, however, had no tingling fingers anymore, the main problem in one of them being a feeling of swollen fingers in the course of the day. One woman reported increased CTS complaints. She was also suffering from diabetes mellitus, but no signs of polyneuropathy were found at the neurophysiological examination. The remaining patient was a man who reported that he still suffered from his complaints in spite of reoperation 27 months earlier.

In all six patients, neurophysiological examination showed a postoperative decrease in deltaDSL between median and ulnar nerves; in three of the six it was found to be within normal limits now. 
Figure 1. Estimated probabilities as a function of deltaDSL

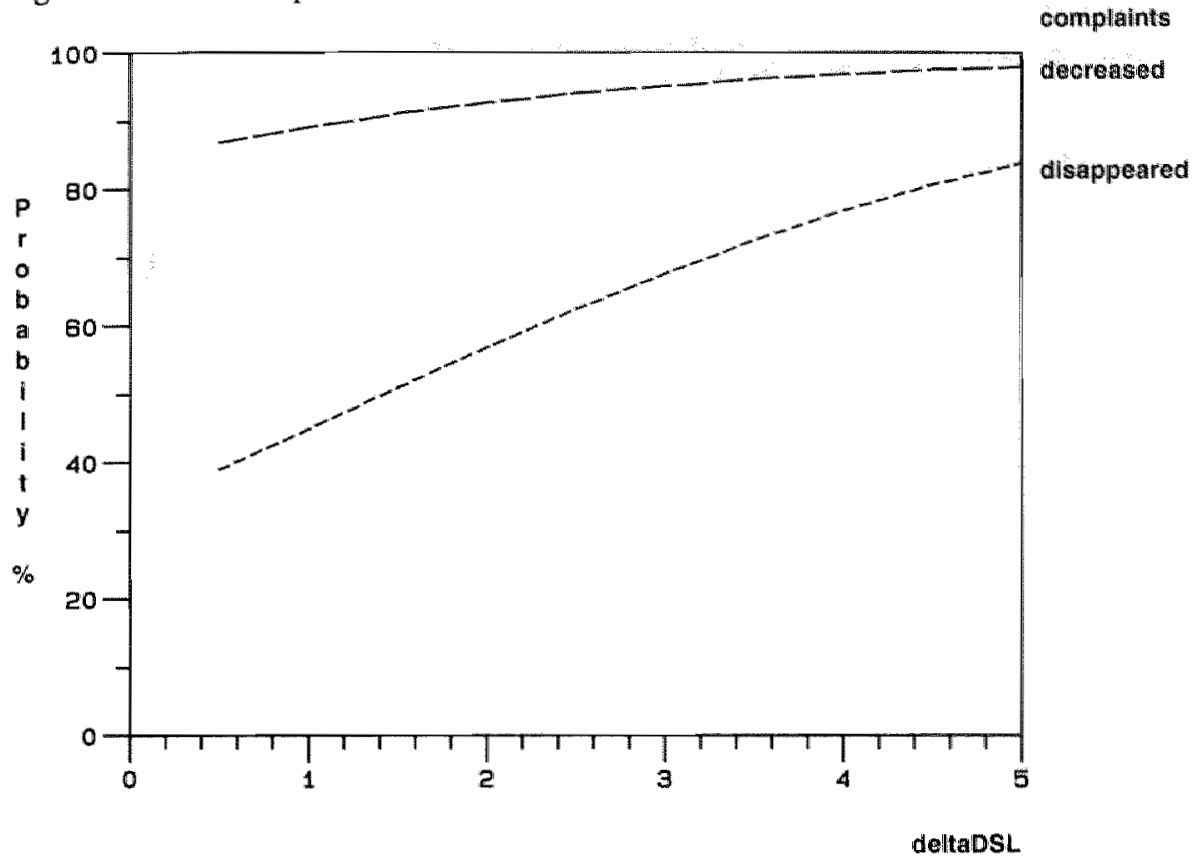

Figure 2. Estimated probabilities as a function of age

complaints

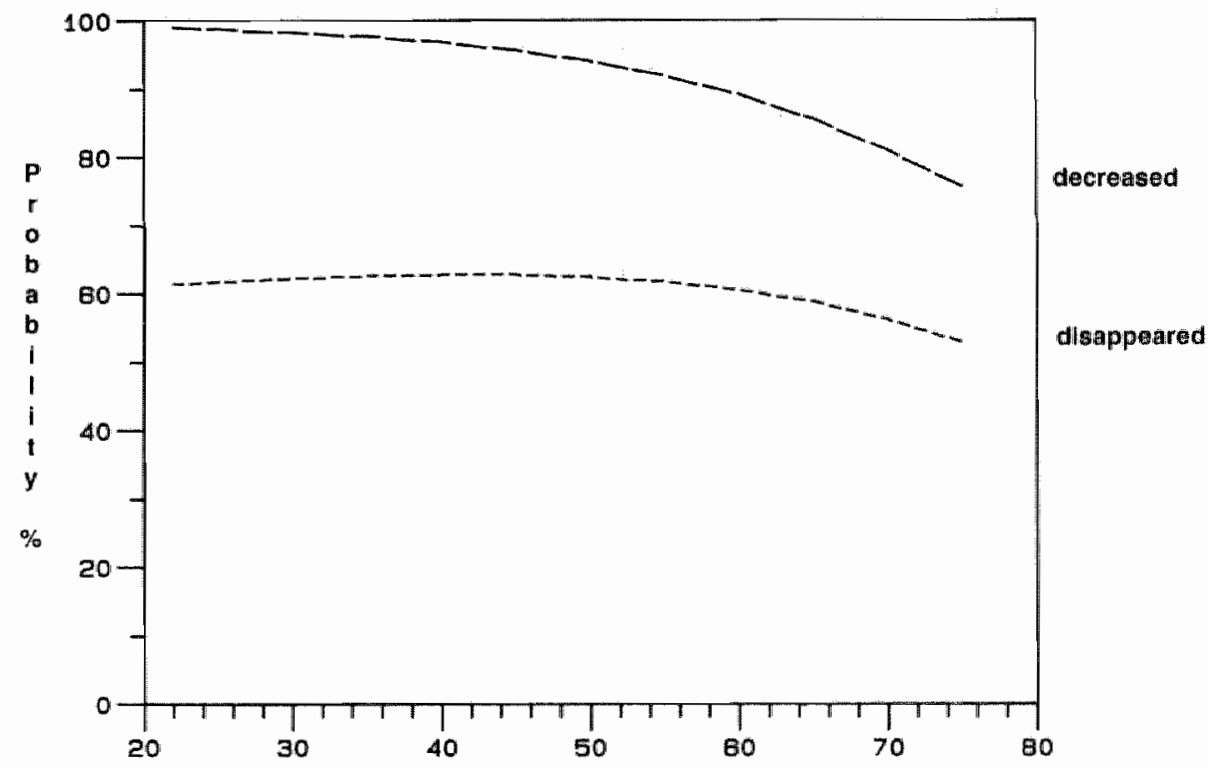

Age, Year 


\section{DISCUSSION}

In an earlier study we found physical examination not to be of chinical value in diagnosing CTS in patients with nocturnal brachialgia (this thesis, chapter 4). For that reason, and because CTS complaints are subjective, we considered questionnaires, completed by the patients themselves, sufficient and reliable means to evaluate the success of surgery.

In our series of CTS patients, 59 per cent were completely cured, 32 per cent had decreased complaints, while nine per cent had unchanged or increased complaints. Of the latter (eleven) patients, only six had a further physical and neurophysiological examination. The impression was that some of these showed improvement.

Table 4. Review of the literature on success rate of surgically treated CTS

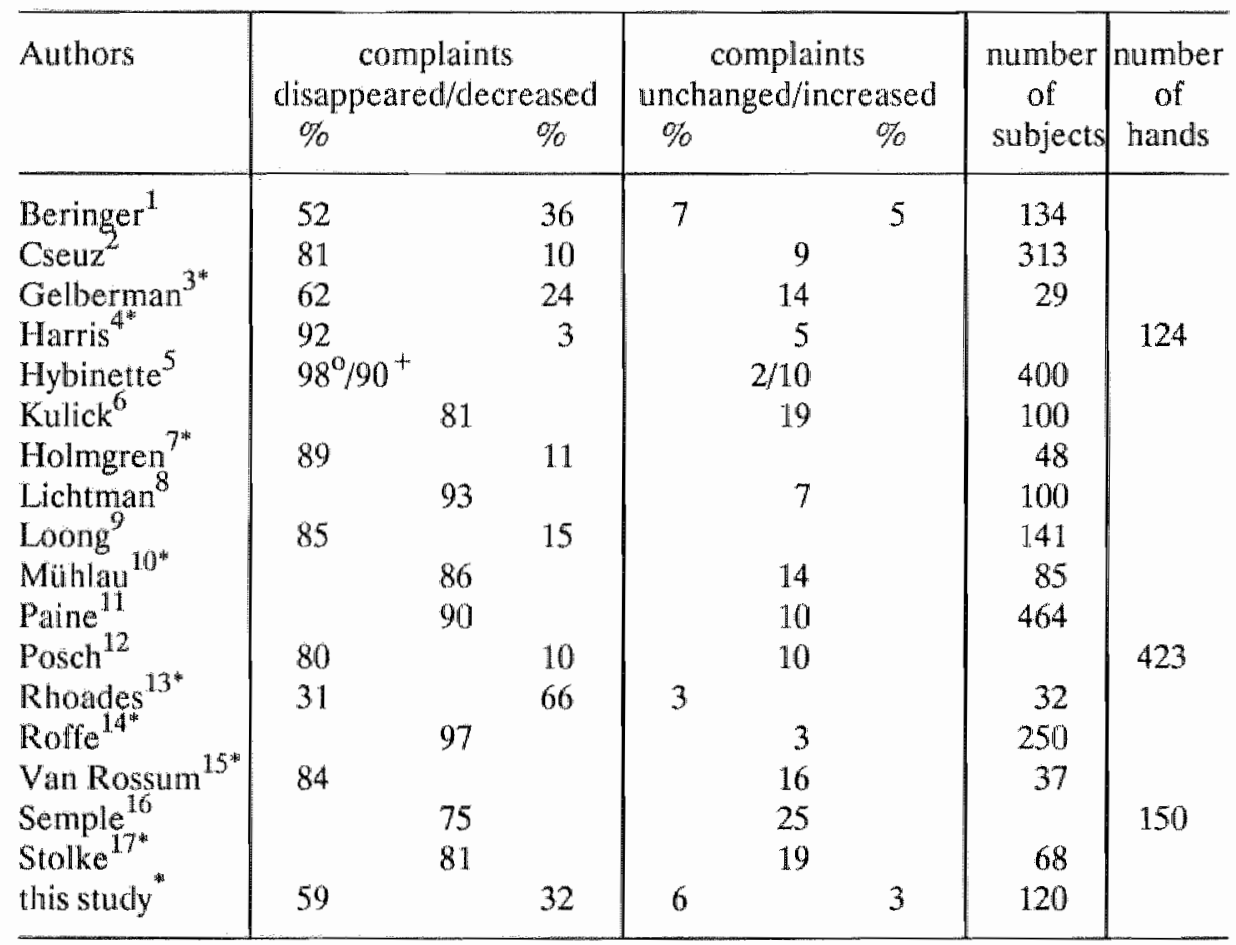

" in all cases CTS diagnosis had been made on the basis of history and abnornal neurophysiological findings

${ }^{\circ}$ pain

thypaest hesia 
The results of various studies on the success rate of surgically treated CTS are summarized in Table 4. In those eight studies in which the diagnosis of CTS had been made on the basis of history and abnormal neurophysiological findings, surgical success rate varied from 81 to 100 per cent with a median of 96 per cent $(3,4,7,10,13-15,17)$. In mine studies in which not all CTS patients had been examined neurophysiologically before operation, 75 to 100 per cent of the patients were symptom-free or had decreased complaints, with a median of 90 per cent $(1,2,5,6,8,9,11,12,16)$. Our success rate of 91 per cent for "complaints disappeared" or "complaints decreased" is in accordance with these findings.

The present investigation shows a lack of association between duration of preoperative complaints and surgical results, which had been demonstrated by others before $(1,3,4,7,20)$. However, our findings contrast with those by Mühlau et al (10), who demonstrated less favourable results when preoperative complaints outlasted seven months, and those of the studies by Posch (12) and by Semple and Cargill (16), who found better results in patients with a short period of preoperative complaints.

Figure 1 shows better results of surgical therapy in patients with higher values for deltaDSL. Roughly the same result was found earlier (4), but contrasts with that by others $(2,3,6,10)$.

In Figure 2, age is shown to have a negative effect on success rate. This result was not found by others $(3,4,10)$, but is in accordance with our experience of every day practice. Two explanations may be suggested for this result:

1. in elderly people the chance of coexisting other disorders causing brachialgia is much greater and surgical treatment of CTS will not treat the other causes of brachialgia.

2. with advancing age the median nerve, which is situated in a vulnerable place in the wrist, will sustain more micro-traumata in comparison with the ulnar nerve. This will result in a greater range of deltaDSLs between median and ulnar nerves. As a result, the diagnosis of CTS may be made too quickly.

A possible explanation for the better results in surgically treated leftsided CTS may be that lefthanded people in a righthanded world use their non aminant land more frequently than righthanded people use their non-dominant left hand. This will reduce the chances of incurring micro-traumata in the left hand and of postoperative pain at the scar.

A clear relation between frequency of preoperative complaints and surgical results was not found, but one may suppose that patients with daily complaints are more easily satisfied with the operation result and will more often report that their complaints have decreased. Patients with less frequent complaints may report complaints unchanged. Table 2 seems to confirm this: the probability of decreased complaints $\mathbb{i s}$ much smaller when preoperative complaints were less than daily.

In conclusion, it may be said that, of the various preoperative parameters considered, age, side of CTS or dominance of hand operated upon, frequency of the preoperative complaints, and deltaDSL between median and ulnar nerves are associated with outcome of surgically treated CTS. 
So far only one study has revealed spontaneous disappearance or decrease of complaints among 32 per cent of 68 CTS patients not operated upon. Because of the high success rate of surgical treatment an experiment comparing surgery with another or no treatment is difficult to perform. The low success rate in our study was found among older patients with deltaDSLs in the lower range of the values considered pathological. Among these patients such an experiment might be ethically justifiable.

\section{REFERENCES}

1. Beringer U. Das Karpaltunnel Syndrom. Analyse von 231 Fälle mit Hinweisen auf die operativen Behandlungsergebnisse. Schweiz med Wschr 1972;102:52-58.

2. Cseuz KA, Thomas JE, Lambert EH, Love GJ, Lipscomb PR. Long-term results of operation for carpal tunnel syndrome. Mayo Clin Proc 1966:41:232-241.

3. Gelberman RH, Pfeffer GB, Galbraith RT, Szabo RM, Rydevik B, Dimick M. Results of treatment of severe carpal tunnel syndrome without internal neurolysis of the median nerve. J Bone Joint Surg 1987;69A:896-903.

4. Harris CM, Tanner E, Goldstein MN, Pettee DS. The surgical treatment of the carpal-tunnel syndrome correlated with preoperative nerve-conduction studies. J Bone Joint Surg 1979;61A, 1,93-98.

5. Hybbinette $\mathrm{CH}$, Mannerfelt $\mathrm{L}$. The carpal tunnel syndrome. A retrospective study of 400 operated patients. Acta Orthop Scand 1975;46:601-620.

6. Kulick MI, Gordillo G, Javidi T, Kilgore ES, Newmeyer III WL, Long-term analysis of patients having surgical treatment for carpal tunnel syndrome. J Hand Surg 1986;11A:59-66.

7. Holmgren-Larsson H, Leszniewski W, Lindén U, Rabow L, Thorling J. Internal neurolysis or ligament division only in carpal tunnel syndrome - results of a randomized study. Acta Neurochir 1985;74:118-121.

8. Lichtman DM, Florio RL, Mack GR. Carpal tunnel release under local anaesthesia: evaluation of the out-patient procedure. J Hand Surg 1979;4(6):544-546.

9. Loong SC. The carpal tunnel syndrome: a clinical and electrophysiological study of 250 patients. Proc Aust Assoc Neurol 1977;14:51-65.

10. Mühlau $G$, Both $R$, Kunath $H$. Carpal tunnel syndrome - course and prognosis. J Neurol 1984;231:83-86. 
11. Paine KWE, Polyzoidis KS. Carpal tunnel syndrome. Decompression using the pain retinacolotome. J Neurosurg 1983;59:1031-1036.

12. Posch JL, Prpic I. Surgical treatment of the carpal tunnel syndrome. Handchirurgie, 1975;7:95-98.

13. Rhoades CE, Mowery CA, Gelberman RH. Results of internal neurolysis of the median nerve for severe carpal tunnel syndrome. J Bone Joint Surg $1985 ; 67 \mathrm{~A}(2): 253-256$.

14. Roffe $J$, Magalon G, Decaillet JM, Latil F, Bureau $H$. Le syndrome du canal carpien. Aspects étiologiques et thérapeutiques actuels. 250 Malades opérés et revus. Nouv Presse Med 1981;10(15):1205-1208.

15. Van Rossum J, Kamphuisen HAC, Wintzen AR. Management in the carpal tunnel syndrome. Clinical and electromyographical follow-up in 62 patients. Clin Neurol Neurosurg 1980;82-3:169-176.

16. Semple JC, Cargill AO. Carpal-tunnel syndrome. Results of surgical decompression. Lancet 1969:918-919.

17. Stolke D, Seidel BU. Das Karpaltunnel Syndrom. Ergebnisse katamnestischer Untersuchungen nach Spaltung des Ligamentum Karpale. Neurochirurgia 1981;24:8486.

18. Agresti A. Analysis of ordinal categorical data. John Wiley and sons, New York, Chichester, Brisbane, Toronto, Singapore, 1984,112-117.

19. Cox C. Multinomial regression models based on continuation ratios. Statistics in Medicine 1988,7:435-i41.

20. Razemon JP. Le syndrome du canal carpien. J Chir (Paris) 1982;119(4):283-294. 
Chapter 5 - appendix

CARPAL TUNNEL SYNDROME

PROGNOSTIC INDICATORS OF SURGICAL SUCCES

The logistic regression model for the analysis is defined as follows:

Let $l_{1}=\log \left\{\left(p_{1}+p_{2}\right) / p_{3}\right\}$ and $l_{2}=\log \left(p_{1} / p_{2}\right)$, where p1, $p_{2}$ and $p_{3}$ are the probabilities of disappeared, decreased and unchanged or increased complaints, respectively. "The estimated model is

$$
\begin{aligned}
& l_{1}=a_{1}+\Sigma b_{j} X_{j} \\
& l_{2}=a_{1}+a_{2}+\Sigma\left(b_{j}+c_{j}\right) X_{j},
\end{aligned}
$$

where $X_{1}, X_{2}$, are the prognostic factors, and $a_{1}, a_{2}, b_{1}, b_{2}, \ldots, c_{1}, c_{2}, \ldots$ are the parameters to be estimated. The c's and b's were assumed to be zero unless significantly different from zero at a $10 \%$ level.

The results are given in table $\mathrm{A} 1$.

Table A 1 . Estimated parameters for logistic regression model

\begin{tabular}{lccc}
\hline parameter & symbol & estimate & s.e.* \\
\hline constant & $\mathrm{a}_{1}$ & 6.19 & 1.75 \\
constant & $\mathrm{a}_{2}$ & -3.39 & 1.89 \\
age (years) & $\mathrm{b}_{1}$ & -0.065 & 0.029 \\
& $\mathrm{c}_{1}$ & 0.072 & 0.033 \\
right hand & $\mathrm{b}_{2}$ & -2.17 & 0.82 \\
non-dominant & $\mathrm{b}_{3}$ & -1.73 & 0.81 \\
daily complaints & $\mathrm{b}_{4}$ & 0.47 & 0.87 \\
& $\mathrm{c}_{4}$ & -2.31 & 1.20 \\
deltaDSL (msec) ** & $\mathrm{bs}^{*}$ & 0.44 & 0.13 \\
\hline
\end{tabular}

* standard error of estimate

* truncated at 5 mseco 
For individual patients, the probabilities $p_{4}, p_{2}$ and $p_{3}$ may be calculated from the "score functions" $l_{1}$ and $l_{2}$ using

$$
\begin{aligned}
\left(p_{1}+p_{2}\right) & =1 /\left\{1+\exp \left(-I_{1}\right\}\right. \\
p_{1} & =\left(p_{1}+p_{2}\right) /\left\{1+\exp \left(-I_{2}\right)\right\} \\
p_{2} & =\left(p_{1}+p_{2}\right)-p_{1} \\
p_{3} & =1-\left(p_{1}+p_{2}\right)
\end{aligned}
$$

From table A1, it follows that the score functions are

$$
\begin{aligned}
\mathrm{l}_{1}=6.19 & -0.065 \times \text { age } \\
& -2.17 \text { if right hand operated } \\
& -1.73 \text { if non-dominant } \\
& +0.47 \text { if daily complaints } \\
& +0.44 \times \text { deltaDSL } \\
\mathrm{l}_{2}=\mathrm{l}_{1} \quad & -3.39+0.072 \times \text { age } \\
& -2.31 \text { if daily complaints. }
\end{aligned}
$$

It might be concluded that the combination of old age, being operated on a right nondominant hand, having had less than daily complaints and a low deltaDSL ( $0.5 \mathrm{msec}$ ) results in a relatively poor prognosis. The score function $I_{\mathbb{1}}$ is then as low as -2.46 and the estimated value of $p_{1}+p_{2}=8 \%$.

However, since the study did not happen to have patients with such a combination of values, this conclusion would imply an unwarranted extrapolation of the regression equation, with no way of knowing whether it is valid or not. In fact, the lowest value of $p_{1}+$ p2 calculated for patients in the study was $54 \%$. 



\section{CHAPTER 6}

\section{CARPAL TUNNEL SYNDROME:}

\section{GENERAL DISCUSSION}

At the out-patient department of neurology at the University Hospital Maastricht, the Netherlands, many patients with brachialgia are seen every year. History and further examination reveal carpal tunnel syndrome (CTS) as the cause in about 120 patients per year. CTS is sometimes thought to occur more frequently now than 20 years ago. This may be the result of a greater awareness of this disease and better diagnostic facilities, or of a greater prevalence of the causes, whatever they may be. In the everyday practice of the neurologist, the prevalence and causes of CTS are frequently discussed not only with the patients but also among doctors. In a great number of the patients physical examination is unremarkable, except for some of the CTS related provocative tests, some of which are positive and others negative. If the diagnosis of CTS is made and the patient is operated upon, (s)he is in many cases free of tingling fingers the night after the operation, and most patients remain symptom-free three to six months after the operation. In a minority of the patients, however, the complaints remain unchanged or are even increased. Because hands are frequently used in our daily activities, this is a serious problem.

Research into primary health care at the University Hospital Maastricht emphasizes the so-called extramural medicine.

For all these reasons, and not least because of our personal interest in patientrelated research, we decided to start an epidemiological study in the general population regarding several aspects of CTS:

1. its prevalence;

2. the diagnostic value of typical complaints;

3. prevalent risk factors;

4. the validity of clinical diagnostic tests"

5 . indicators of the prognosis of surgical treatment.

A special problem was the lack of a clear definition of CTS in the literature. For that reason we studied the history in a group of 128 patients operated upon for CTS. The diagnosis had been made by one of the seven neurologists at our hospital on the basis of history and abnormal neurophysiological findings. Of these patients, 99 per cent complained of tingling, 89 per cent of pain, and 88 per cent of numbness in their median nerve innervated fingers occurring at least twice a week. At least one of these 
complaints was found in all $128 \mathrm{CTS}$ patients. Ninety-five per cent of them woke up because of (one of) these complaints.

As the literature does not agree on the value of various clinical diagnostic tests, these tests were not considered to be criteria for our diagnosis of CTS.

It might be suggested to include in the definition a good surgical treatment result. However, that would limit the definition to subjects with possibly more severe forms of CTS and suggest that only surgery is successful in the treatment of CTS.

With other authors we agree that a typical history alone is not sufficient to diagnose CTS. Abnormal findings in neurophysiological examination must be demonstrated as well (1-3). The results of the various neurophysiological methods which have been practiced at our department of clinical. neurophysiology, show that comparing distal sensory latency (DSL) of the median nerve with that of the uinar nerve (as recorded at the ring-finger after stimulation proximal of the carpal ligament) is the most reliable test to detect an entrapment of the median nerve in the carpal tunnel. Several authors prefer orthodromic measurements with palmar stimulation, others use antidromic measurements with stimulation at the wrist and recording from the fingers. Our upper "normal" neurophysiological value for the difference in distal sensory latency (deltaDSL) to digit IV is somewhat higher than that chosen by others $(4,5)$ and is in accordance with the value found by Redmond and Rivner using the orthodromic method (6).

On the basis of the findings from the history of our 128 CTS patients, the experience of our department of clinical neurophysiology, and the literature on this subject, we decided to take as our gold standard for CTS the combination of typical history (paraesthesiae, numbness and/or pain in the median nerve innervated fingers at least twice a week, which in most cases wake up the patient) and abnormal nerve conduction of the median nerve at the wrist, in the absence of neurographic signs of polyneuropathy.

Using this definition we performed a cross-sectional study of the (undetected) prevalence of CTS in the general population. We found that 13 per cent of the subjects from an age and sex stratified random sample woke up due to paraesthesiae, pain and/or numbness in their fingers, i.e. brachialgia paraesthetica nocturna. Of the patients with this remarkably frequent complaint, 38 per cent showed an abnormal nerve conduction of the median nerve at the wrist.

Undetected CTS was calculated to occur in 5.8 per cent $(95 \%$ confidence interval (CI): $3.5-8.1 \%$ ) of the adult female population. Another 3.4 per cent $(95 \% \mathrm{CI}: 1.5$ $5.3 \%$ ) had already been diagnosed as CTS. The overall prevalence rate for men was found to be low: 0.6 per cent $(95 \% \mathrm{CI}: 0-2 \%)$. These figures have to be regarded as minimal estimates.

Among the subjects with nocturnal brachialgia approximately 22 per cent refused to have a neurophysiological examination at the hospital. We assumed them to be free of CTS, thus calculating a minimum prevalence rate. However, if we assume that their prevalence rate equals that of the responders, the undetected prevalence rate is increased by 28 per cent. For adult women this means 7.4 instead of 5.8 per cent.

In addition, it is possible that we have overlooked a few CTS patients who reported 
in the interview that their brachialgia did not wake them up at night or whose neurophysiological examination was false-negative.

It is important to know that the prevalence rate of CTS is so high. The preceding figures illustrate that more than half of the CTS patients go unrecognized. "The patient's brachialgia is attributed to many different causes. These include "postmenopausal problems", cervical arthrosis, cervical root compression, rhenmatism, arthrosis of the wrist, surmenage and vascular diseases. Doctors who are familiar with the high prevalence rate of CTS will more frequently consider CTS as the cause of brachialgia. Our research has shown that the simple question: "Do you wake up at night due to tingling, pain or numbness in your fingers?" is a good screening device. If this question is answered in the affirmative, the chance of having CTS will be 45 per cent in women, and 38 per cent in men and women together.

As for the reasons for such a high prevalence rate of CTS in the general population, the following possibilities may be suggested:

1. CTS is not a fatal disease.

2. CTS is the result of cumulative micro-traumata of the median nerve at the wrist, so with advancing age more patients with CTS will be found.

The difference in prevalence of CTS among men and women may be explained as follows:

1. in their domestic and professional work women endure more micro-traumata of the median nerve in the wrist than most men do in their activities;

2. as a rule women have a shorter stature, a higher weight and a higher Quetelet index than men, which are shown to be risk indicators;

3. women perceive their body differently and may consult their GP more frequently during their perimenopausal years, so a carpal tunnel syndrome will be discovered more easily.

Prevalent risk indicators for CTS were studied in a population-based case-control study. Activities with a flexed or an extended wrist were each shown to carry an exposure related increased risk for CTS. These findings are in accordance with measurements showing an elevated pressure in the carpal tunnel during flexion or extension of the wrist. This elevated pressure has also been shown to impair the median nerve conduction velocity at the wrist (7). To our surprise the association between combined activities of the wrist in flexion and extension and CTS was a rather weak one. Neither did we find a relation with typewriting or pinch grasping.

With regard to female-related factors, the use of oral contraceptives could not be identified as a risk factor for CTS. In contrast, previous hysterectomy and recent menopause were demonstrated to carry an increased risk for CTS. To explain this, one might suppose that women with a previous hysterectomy or with a recent menopause have been consulting their doctors more frequently. Hence they might have had a greater chance of detection of their CTS. However, the male:female ratio in the general population was found to be 1:12 whereas in the hospital series of CTS patients 
it was 1:4. Therefore, this assumption is not valid. In the case of hysterectomy, the removal of a special protective factor might be suggested the cause; in the case of recent menopause it might be a sudden change in the endocrine status.

Other results of our etiological study were that a higher weight and Quetelet index were associated with an increased risk for CTS. Moreover, subjects of a shorter stature were more at risk. They may have a smaller carpal canal size, which has already been demonstrated to be a risk factor for CTS (8). Slimming courses were also found to carry an increased risk for CTS.

In the general population the male:female ratio among CTS patients was 1:12, whereas in our hospital series of CTS patients the male:female ratio is 1:4. This suggests that CTS will be discovered earlier in men. It may be assumed that men have to do their job, resulting in a continuously, imposed exposure to risk factors. In contrast, most women are more free to choose their own exposure to the risks of work/domestic activities.

As a result of the design of this study and the low prevalence of patients with diabetes mellitus, thyroid diseases, rheumatism, wrist fractures and of patients on hemodialysis in the general population we were unable to identify these as risk factors for CTS.

We also performed a cross-sectional study on the validity of various CTS related clinical diagnostic tests. "This study was done in the general population. In the literature many of these tests have been advocated as valuable tools in the diagnosis of CTS. However, we were unable to show that they substantially changed the probability of CTS in subjects with nocturnal brachialgia. To explain this inconsistency we suppose that the results of previous studies have been influenced by referral bias and disease severity bias. Only those patients may have been referred to the hospital who had positive CTS related clinical diagnostic tests and/or who had very severe forms of CTS with e.g. severe thenar atrophy. By taking an age and sex stratified random sample from the general population we managed to prevent both biases. In our study of the population of patients with nocturnal brachialgia we found a low validity for all clinical diagnostic tests. Neither was a combination of tests (all negative or positive) of clinical relevance. So, there is no longer any need to perform these CTS related clinical diagnostic tests in everyday general practice.

Finally we performed a non-experimental cohort study of prognostic indicators for the success of surgery among CTS patients. Reviewing the literature a study in which a considerable number of CTS patients is randomly operated upon or treated with conservative measures was still found to be lacking. Furthermore, it was surprising that there was no great difference in success rate between the studies in which CTS diagnosis had been made on the basis of clinical history and abnormal neurophysiological findings and the studies in which a typical clinical history alone was considered to be sufficient. Our success rate of 91 per cent is in accordance with the data found in the literature. Such a high success rate of the treatment of CTS stresses the importance of detecting CTS as the cause of nocturnal brachialgia. Our screening device (do you wake up at night because of tingling, pain or numbness in your fingers?) has a relative- 
ly high diagnostic value, is easy and cheap, and does not burden the patient.

One of the main findings of our prognostic study was that results were poorer in older patients and in patients with low values for deltaDSL. One may suppose that older patients have a greater chance of suffering from co-existing diseases (which will not be treated by surgical release of the median nerve at the wrist). They may also have sustained many more micro-traumata of the median nerve in the wrist. Furthermore, a positive association between age and median nerve sensory latency has been demonstrated (2). As a result, the range of the values considered normal for median nerve conduction velocity at the wrist may become wider with advancing age, which will lead to a greater chance of CTS diagnosis. Further research into the efficacy of surgical treatment compared to conservative treatment may be ethically justified in older CTS patients with less severe slowing of the nerve conduction of the median nerve at the wrist.

Many items connected with CTS remain to be studied. For example, we did not study:

- the anatomical relations in the carpal tunnel between the median nerve, the connective tissue apparatus and the flexor tendons;

- the value of the various neurophysiological methods in relation to the gravity of the CTS complaints;

- the prevalence of CTS among patients with diseases which are supposed to increase the risk for CTS, like diabetes mellitus, thyroid diseases, wrist fractures and renal diseases necessitating hemodialysis;

- the prevalence of CTS in employees of special industries, who have long-lasting exposures to activities with either the flexed or the extended wrist, before and after an intervention period in which working positions of the wrist are improved and handtools are adlapted;

- the value of conservative treatment of CTS as opposed to surgical treatment in older patients with less severe slowing of the median nerve conduction at the wrist.

Furthermore, we feel that, especially with respect to female related risk factors, our results still need confirmation.

\section{WHICH LESSONS CAN BE LEARNED FROM THIS THESIS?}

- For general practitioners: CTS is a prevalent disease which can easily be detected. Ask your patient with brachialgia: "Do you wake up at night due to tingling, pain or numbness in your fingers?". If the answer is "yes", refer the patient for further neurological/neurophysiological examination. If this proves to be positive the patient should be advised to be operated upon for CTS. If the answer is "no" other causes of brachialgia should be considered first.

- For medical students: stop burdening your memory with CTS related clinical diagnostic tests. 
- For neurologists, neurosurgeons and other medical specialists involved in the treatment of CTS: surgical treatment of CTS is highly successful, but watch out for old ladies with borderline nerve conduction disturbances.

\section{REFERENCES}

1. Aebi-Ochsner C, Ludin HP. Das Karpaltunnelsyndrom - klinische Symptomatologie und Electrophysiologische Befunde. Fortschr Neurol Psychiatr $1979 ; 47(6): 307-319$.

2. Nathan PA, Meadows KD, Doyle LS. Relationship of age and sex to sensory conduction of the median nerve at the carpal tunnel and association of slowed conduction with symptoms. Muscle and Nerve 1988;11:1149-1153.

3. Melvin JL, Schuchmann JA, Lanese RR. Diagnostic specificity of motor and sensory nerve conduction wariables in the carpal tunnel syndrome. Arch Phys Med Rehabil 1973;54:69-74.

4. Brenninkmeyer $R$. The carpal tunnelsyndrome and the antidromic sensory latencies to the first and the fourth finger. Abstracts 6th International Congress of Electromyography, Stockholm. Acta Neurol Scand 1979;suppl 73,60:119.

5. Johnson EW, Kukla RD, Wongsam PE, Piedmont A. Sensory latencies to the ring finger: normal values and relation to carpal tunnel syndrome. Arch Phys Med Rehabil 1981;62:206-208.

6. Redmond MD, Rivner MH. False positive electrodiagnostic tests in carpal tunnel syndrome. Muscle and Nerve 1988;11:51 1-517.

7. Lundborg GN, Gelberman RH, Minteer-Convery M, Lee YF, Hargens AR. Median nerve compression in the carpal tunnel - functional response to experimentally induced controlled pressure. J Hand Surg 1982;7:252-259.

8. Bleecker ML, Bohlman M, Moreland R, Tipton A. Carpal tunnel syndrome: role of carpal canal size. Neurology 1985;35:1599-1604. 


\section{CHAPTER ?}

\section{CARPAL TUNNEL SYNDROME:}

SUMMARY

This thesis presents the results of a study of various epidemiological aspects of carpal tunnel syndrome (CTS). The carpal tunnel is a canal at the palmar side of the wrist, which is composed of the carpal bones on one side and the carpal ligament on the other. This closes the carpal groove and is part of an oval connective tissue apparatus, which is smaller than the bony groove. The contents of the carpal tunnel are: 1) the median nerve, situated immediately under the carpal ligament; and 2) the nine flexor tendons of the superficial and profound flexor muscles of the fingers.

Entrapment of the median nerve under the carpal ligament resuits in the so-called CTS. Complaints due to CTS include pain, numbness and/or tingling in the median nerve innervated fingers, i.e. thumb, index, middle-finger and the radial half of the ring-finger. Most patients wake up at night because of these complaints. Some people with CTS report complaints in all fingers or radiating up the arm towards, or even beyond the elbow, as well as sensory disturbances in their finger-tips or weakness of grip. Frequently, findings at physical examination are unremarkable. This clinical history is indicative for CTS but is not considered to be sufficient to establish the diagnosis. Abnormal findings at neurophysiological examination must be present as well.

Our gold standard is a combination of the typical history (tingling, pain and/or numbness in the median nerve innervated fingers, which in most cases wake up the patient at right) and abnormal nerve conduction of the median nerve at the wrist.

Our special interest was in CTS among subjects in the general population and extramural care. Participants of the study were taken as an age and sex stratified random sample from the population register of Maastricht, the Netherlands, and surrounding villages, and from a series of consecutive CTS patients diagnosed at the out-patient department of neurology, University Hospital Maastricht. All were interviewed using a standardized questionnaire with items on general health, putative CTS risk indicators and CTS complaints.

Chapter 2 reports on a cross-sectional study of the undetected prevalence of CTS in the general population. In 504 subjects we identified one man and 23 women who had CTS. Taking the age distribution of the Dutch population as the standard we arrived at 
a conservative prevalence estimate of undetected CTS in adult men of 0.6 per cent (95\% confidence interval (CI): $0-2 \%$ ) and in adult women of 6 per cent (95\% Cl: $4-$ 8\%). Another 3 per cent ( $95 \% \mathrm{Cl}: 2.5 \%$ ) of the adult women had already been diagnosed as having CTS.

In chapter 2 we also discuss the diagnostic wallue of the complaint "waking up at night because of nocturnal brachialgia", i.e. the complaints mentioned above. The diagnostic value of this complaint was 8 per cent $(95 \% \mathrm{CI}: 0-36 \%$ ) in men, and 45 per cent (95\% Cl: $31-60 \%)$ in women.

Chapter 3 describes a population-based case-control study on prevalent risk indicators for CTS. In the age and sex stratified random sample from the general population already mentioned, all subjects with clinical and neurophysiological proof of CTS were identified and added to a series of consecutive CTS patients, diagnosed at the out-patient department of neurology of the University Hospital Maastricht. Their data were compared with those of the remaining subjects from the general population. Our most striking finding was the association of CTS with activities of the extended or the flexed wrist. This risk proved to be exposure related among subjects who were involved in such activities. Compared to subjects who do not burden their wrists, subjects who do so for 40 hours a week turned out to have a $4-5$ times higher probability of contracting CTS. There seems to be an association between CTS and certain female factors such as hysterectomy and recent menopause as well. Finally, the study showed that obese subjects of a short stature run an increased risk of contracting CTS.

Chapter 4 evaluates the validity of 12 CTS related clinical diagnostic tests in a crosssectional study in the general population. Patients with nocturnal brachialgia were identified and clinically tested. Afterwards the median nerve conduction velocity was examined neurophysiologically. It turned out that none of the clinical diagnostic tests nor a combination of several tests, changed the prior probability of CTS (47\% in this series) substantially. It is concluded that these clinical diagnostic tests appear to be invalid acts, which do not contribute to the diagnosis.

Chapter 5 reports on a non-experimental cohort study on the success of the surgical treatment of CTS in relation to prognostic indicators . A series of consecutive patients operated upon for CTS was followed up for more than six months. Of these 59 per cent reported to be symptom-free, 32 per cent reported that their complaints had decreased, while nine per cent had unchanged or increased complaints. We found higher success rates in patients with more severely disturbed conduction of the median nerve at the wrist, in younger patients, in left-handed people who are operated upon for a left-sided CTS and in people who had daily complaints in the preoperative period. On the basis of these findings further research is suggested into the efficacy of surgical treatment compared to conservative measures, especially in older CTS patients with less severely disturbed nerve conduction wellocity of the median nerve at the wrist.

Chapter 6 presents a general discussion of the findings in this thesis. It ends with suggestions for further studies and some lessons to be learned for medical practice and research. 


\section{CHAPTER 8}

\section{CARPAL TUNNEL SYNDROME:}

\section{SAMENVATTING}

In dit proefschrift worden de resultaten beschreven van een epidemiologisch onderzoek naar verschillende aspekten van het carpale tunnelsyndroom (CTS). Het gaat daarbij om het vórkomen van CTS in de algemene bevolking, faktoren die het ontstaan van CTS bepalen, de betekenis van klachten en fysisch diagnostische tests voor de diagnose CTS, en tenslotte faktoren die het succes van een CTS operatie bepalen.

De carpale tunnel is een kanaal aan de handpalmzijde van de pols en bestaat enerzijds uit de U-vormig gerangschikte polsbotten en anderzijds uit het carpale ligament. Het carpale ligament is een bindweefselstruktuur die de benige polsgroeve afsluit en is onderdeel van een tunnelvormige, ovale bindweefselstruktuur die kleiner is dan en gelegen is in deze benige polsgroeve. De inhoud van de carpale tunnel bestaat uit:

1. de onmiddellijk onder het carpale ligament gelegen nervus medianus, de middelste zenuw, en

2. de negen pezen van de oppervlakkige en diepe vingerbuigspieren.

Beknelling van de nervus medianus onder het carpale ligament geeft het zo geheten CTS. De klachten die hierbij worden gezien zijn tintelingen, pijn en/of gevoelloosheid in de door de nervus medianus verzorgde huid aan de handpalmzijde van de duim, de wijsvinger, de middelvinger en de tegen de middelvinger aangelegen helft van de ringvinger. Als gevolg van deze klachten worden CTS patiënten 's nachts meestal uit hun slaap gewekt (nachtelijke brachialgie). Sommige mensen met een CTS hebben zelfs in alle vingers klachten waarbij de pijn uitstraalt naar de onderarm, de elleboog of zelfs daarboven, stoornissen in het gevoel van hun vingertoppen en minder kracht in hun hand. Het lichamelijke onderzoek is bij deze patiënten vaak zonder afwijkingen. Op grond van literatuuronderzoek menen wij dat bevestiging van de diagnose CTS door middel van neurofysiologisch onderzoek (waarbij o.a. de zenuwgeleiding van de nervus medianus over de pols bepaald wordt) noodzakelijk is. Van alle methoden van zenuwgeleidingsonderzoek lijkt bij onze patiënten het vergelijken van de distale sensibele latentietijd van de nervus medianus met die van de nervus ulnaris naar de vierde vinger na stimulatie ter hoogte van de pols, de meest betrouwbare, indien een CTS vermoed wordt. Onze definitie van CTS is een kombinatie van

1) de typische klachten van nachtelijke brachialgie;

2) de afwijkende bevindingen bij het zenuwgeleidings-onderzoek. 
Het hier beschreven onderzoek richt zich speciaal op CTS in de algemene bevolking. De deelnemers aan het onderzoek zijn verkregen door een steekproef uit het bevolkingsregister van Maastricht en omgevende dorpen te trekken. Daarnaast is de medewerking verkregen van een groep patiênten van de polikliniek neurologie, Academisch Ziekenhuis Maastricht, bij wie de diagnose CTS gesteld was. Bij al deze mensen is een enquête afgenomen met vragen over de algemene gezondheid, veronderstelde CTS risiko-indikatoren, CTS klachten, etc.

Hoofdstuk 2 geeft de resultaten van een onderzoek van de prevalentie van nog niet herkend CTS in een dwarsdoorsnede van de algemene bevolking. In een groep van 504 personén werden één man en 23 vrouwen gevonden die een CTS hadden. Indien de leeftijdsverdeling van de Nederlandse bevolking als de standaard wordt aangehouden, dan is volgens een konservatieve schatting de prevalentie van nog niet herkend CTS onder wolwassen mannen 0.6 procent (95\% betrouwbaarheidsinterval (BI): $0-2 \%$ ) en onder volwassen vrouwen 6 procent (95\% BI: $4-8 \%$ ). Bij nog eens 3 procent (95\% BI: $2-5 \%$ ) van de volwassen vrouwen bleek al eerder een CTS te zijn vastgesteld.

In hoofdstuk 2 wordt bovendien een onderzoek beschreven naar de diagnostische waarde van de klacht: 's nachts wakker worden ten gevolge van tintelingen, pijn en/of gevoelloosheid in de hand (nachtelijke brachialgie). De diagnostische waarde van deze klacht voor CTS was voor mannen 8 procent ( $95 \%$ BI: 0-36\%) en voor vrouwen 45 procent (95\% BI: 31-60\%).

Hoofdstuk 3 beschrift een case-control onderzoek in de algemene bevolking naar risiko-indikatoren voor CTS. In de hierboven reeds beschreven steekproef uit de algemene bevolking zijn alle personen met een CTS opgespoord en gevoegd bij een groep patiënten bij wie de diagnose CTS gesteld is op de polikliniek neurologie van het Academisch Ziekenhuis Maastricht. De gegevens over risiko-indikatoren van deze CTSgroep zijn vergeleken met die van de personen die overbleven uit de steekproef van de algemene bevolking. Opvallend was de associatie van CTS met aktiviteiten, waarbij de pols in extensie of in flexie gehouden wordt. De kans op CTS hangt samen met de duur van deze aktiviteiten. In vergelijking met personen die geen polsbelastende aktiviteiten hebben, blijken personen, die deze gedurende 40 uur per week volhouden, een kans op CTS te hebben die vier- tot vijfmaal zo hoog is. Verder lijkt er een samenhang te zijn tussen CTS en bepaalde vrouwelijke faktoren zoals het ondergaan hebben van een operatie waarbij de baarmoeder verwijderd is, of het recent begonnen zijn aan de overgang. Tot slot toont dit onderzoek aan dat CTS relatief veel voorkomt bij zwaarlijvige, korte mensen.

In hoofdstuk 4 wordt de waarde van 12 klinisch-diagnostische tests op CTS onderzocht in een dwarsdoorsnede van de algemene bevolking. Patiënten, die 's nachts gewekt worden door brachialgie, zijn in de reeds genoemde steekproef opgespoord en onderzocht, terwijl bovendien de zenuwgeleidingssnelheid van de nervus medianus neurofysiologisch bepaald is. Geen enkele van de klinisch-diagnostische tests, noch een kombinatie ervan, blijkt de op voorhand reeds bestaande waarschijnlijkheid op een 
CTS (die in deze groep 47 procent was) beduidend te veranderen. Op grond hiervan is de konklusie gerechtvaardigd dat deze klinisch-diagnostische tests niet mér zijn dan loze handelingen, die de waarschijnlijkheid van de diagnose CTS bij mensen met nachtelijke brachialgie nauwelijks veranderen.

In hoofdstuk 5 wordt een niet-experimenteel kohort-onderzoek beschreven waarbij het succes van chirurgische behandeling van het CTS gerelateerd wordt aan de waarde van diverse prognostische indikatoren. Een groep van 120 patiënten werd meer dan zes maanden na de CTS operatie geënquêtteerd. Van deze patiënten blijkt 59 procent geen klachten meer te hebben, 32 procent meldt een vermindering van de klachten, terwijl negen procent dezelfde of zelfs toegenomen klachten heeft. De operatie blijkt een betere kans van slagen te hebben bij patiënten met een ernstigere geleidingsstoornis van de nervus medianus over de pols, bij jongere patiënten, bij linkshandige patiënten die aan hun linkszijdig CTS geopereerd zijn, en bij patiênten die vó́r de operatie dagelijks klachten hadden aan hun geopereerde hand. Op grond van onze bevindingen lijkt het gerechtvaardigd een onderzoek op te zetten naar het nut van de chirurgische behandeling van CTS, in vergelijking met konservatieve behandeling, speciaal bij oudere mensen met een CTS, die een minder ernstig gestoorde zenuwgeleiding hebben van de nervus medianus over de pols.

In hoofdstuk 6 volgt een algemene bespreking van de bevindingen van het beschreven epidemiologische onderzoek. Ook worden hierin mogelijkheden voor verder onderzoek in de toekomst aangegeven. 



\section{ACKNOWLEDGEMENT}

I am much indebted especially to Paul Knipschild, Arnold Kester and Thera van Lieshout. Furthermore I should like to express my gratitude to Tiny Bastiaens-Aarts, Fokko Boekkooi, Valeria Boesten, Jan Drukker, Jan. Klerkx, Paul van der Lugt, Bart Slooff, Frank Spaans, Gaston Stassen, Carel Thijs, Wilma van de Ven and the many people from Maastricht and its surrounding villages who were willing to co-operate in this epidemiological study. 



\section{CURRICULUM VITAE}

Marcus C.T.F.M. de Krom

4 september 1948

1 juni 1967

25 april 1975

1 mei 1976

1 mei 1979

1 juni 1979 tot heden: geboren te Goirle (N.B.)

examen gymnasium ß St Odulphuslyceum, Tilburg

artsexamen Rijksuniversiteit Leiden

beëindiging opleidingsjaar psychiatrie, Ursulakliniek Wassenaar, J.A.M. Ceha en C.V.J. Gemke, psychiaters

beëindiging opleiding tot neuroloog, Ursulakliniek Wassenaar, later Westeinde ziekenhuis, Den Haag. Opleiders achtereenvolgens Dr. J.M.J. Tans, Dr. J.H.A. van der Drift, Dr. L.C.M. Moll. Stage Kinderneurologie (6 maanden), opleider: Dr.A.C. van Huffelen, kinderneuroloog. Stage Neurochirurgie ( 3 maanden), opleiders: Dr, M.Th.A. van Duinen, Dr. C.A.F. Tulleken, neurochirurgen.

neuroloog, staflid vakgroep Neurologie, Ziekenhuis St. Annadal, later Academisch Ziekenhuis Maastricht, in samenwerking met Prof.dr. P.J.M. van der Lugt, Dr. G. Padberg (tot 1 oktober 1982), F.W. Vreeling, Dr. C.J. Höweler, Dr. A. Twijnstra, Dr. J. Lodder Dr. J.S.H. Vles en R.M.M. Hupperts, neurologen. 